University of Nebraska - Lincoln

DigitalCommons@University of Nebraska - Lincoln

Faculty Publications from the Harold W. Manter Laboratory of Parasitology

$10-2004$

Phylogeny for Species of Haemonchus (Nematoda:

Trichostrongyloidea): Considerations of Their Evolutionary History

and Global Biogeography among Camelidae and Pecora (Artiodactyla)

Eric P. Hoberg

United States Department of Agriculture, eric.hoberg@ars.usda.gov

J. Ralph Lichtenfels

Animal Parasitic Disease Lab, ARS, United States Department of Agriculture, 2jrcgl@gmail.com

Lynda M. Gibbons

University of London

Follow this and additional works at: https://digitalcommons.unl.edu/parasitologyfacpubs

Part of the Parasitology Commons

Hoberg, Eric P.; Lichtenfels, J. Ralph; and Gibbons, Lynda M., "Phylogeny for Species of Haemonchus (Nematoda: Trichostrongyloidea): Considerations of Their Evolutionary History and Global Biogeography among Camelidae and Pecora (Artiodactyla)" (2004). Faculty Publications from the Harold W. Manter Laboratory of Parasitology. 324.

https://digitalcommons.unl.edu/parasitologyfacpubs/324

This Article is brought to you for free and open access by the Parasitology, Harold W. Manter Laboratory of at DigitalCommons@University of Nebraska - Lincoln. It has been accepted for inclusion in Faculty Publications from the Harold W. Manter Laboratory of Parasitology by an authorized administrator of DigitalCommons@University of Nebraska - Lincoln. 


\title{
PHYLOGENY FOR SPECIES OF HAEMONCHUS (NEMATODA: TRICHOSTRONGYLOIDEA): CONSIDERATIONS OF THEIR EVOLUTIONARY HISTORY AND GLOBAL BIOGEOGRAPHY AMONG CAMELIDAE AND PECORA (ARTIODACTYLA)
}

\author{
Eric P. Hoberg, J. Ralph Lichtenfels, and Lynda Gibbons*
}

U.S. National Parasite Collection and the Animal Parasitic Diseases Laboratory, USDA, Agricultural Research Service, BARC East 1180,10300

Baltimore Avenue, Beltsville, Maryland 20705-2350.e-mail: ehoberg@anri.barc.usda.gov

\begin{abstract}
Phylogenetic analysis of 25 morphological characters among the 12 species of Haemonchus resulted in 1 most parsimonious tree (60 steps; consistency index $=0.67$, retention index $=0.80$ ). Monophyly for Haemonchus was diagnosed by 3 unequivocal synapomorphies, including the asymmetric origin of the dorsal ray, relative size of the ventral rays, and the presence of a barb on each spicule tip. Species of Haemonchus have complex histories with respect to host and geographic associations: (1) origins in Africa with basal diversification in antelopes (H. krugeri, H. lawrencei, H. dinniki, H. horaki), (2) independent events of colonization for those species in Caprini and Bovinae (H. contortus, H. placei, H. bedfordi, H. similis), (3) colonization and development of core host associations within Camelidae (H. longistipes) and among Antilopinae, Tragelaphini, and Giraffidae (H. mitchelli, H. okapiae, H. vegliai), and (4) geographically widespread species that are represented only by those that have been translocated with domestic stock. The North American fauna is characterized by 3 introduced and exotic species, H. placei, H. contortus, H. similis, which emphasizes the importance of continued documentation of faunal diversity in the context of predictive foundations derived from phylogenetic studies. Satellite associations for species of Haemonchus, particularly among Cervidae and Camelidae in the Neotropics and Cervidae, Antilocapridae, and possibly wild Caprinae in the Nearctic, have been a consequence of introductions and exchange of parasites at historical interfaces for managed and natural ecosystems. Such distributions are emblematic of the overriding significance of anthropogenic factors as determinants of the global distributions for pathogenic parasites in domestic and wild ruminants.
\end{abstract}

Species of Haemonchus Cobb, 1898 are abomasal nematodes and often significant pathogens that occur among a diverse assemblage of artiodactyl hosts including species among 46 genera of Camelidae and Pecora encompassing the Antilocapridae, Giraffidae, Cervidae, and Bovidae. Haemonchus represent the most economically important helminth parasites in cattle, sheep, and goats throughout the world (Gibbs and Herd, 1986), and considerable research has been conducted on those species, $H$. contortus (Rudolphi, 1803), H. placei (Place, 1893), and $H$. similis, Travassos, 1914, that are globally distributed in domesticated Bovinae and Caprinae. Another 7 species, H. bedfordi Le Roux, 1929, H. dinniki Sachs, Gibbons and Lweno, 1973, $H$. horaki Lichtenfels, Pilitt, Gibbons and Boomker, 2001, $H$. krugeri Ortlepp, 1964, H. lawrencei Sandground, 1933, H. mitchelli Le Roux, 1929, and H. vegliai Le Roux, 1929, are primary parasites among respective host groups and species of wild Bovinae, Cephalophinae, Reduncinae, Aepycerotinae, Antilopinae, Alcelaphinae, and Caprinae in sub-Saharan Africa, whereas H. okapiae van den Berghe, 1937 occurs in Giraffidae, and H. longistipes Railliet and Henry, 1909 occurs in Camelidae and domestic sheep, goats, and rarely, cattle across a broader range extending from Africa to southern Eurasia (Gibbons, 1979; Jacquiet et al., 1995; Lichtenfels et al., 2001, 2002). Although as a group these nematodes have been the focus of considerable taxonomic study, there has been no previous attempt to elucidate phylogenetic relationships among the recognized species of Haemonchus (e.g., Almeida, 1935; Gibbons, 1979).

Haemonchus has long been regarded as an inclusive group within the Trichostrongylidae sensu Hoberg and Lichtenfels (1994) or the Trichostrongyloidea sensu Durette-Desset et al. (1999) and the subfamily Haemonchinae Skrjabin and Schul'ts, 1952 (see Skrjabin et al., 1954). Durette-Desset and Chabaud

Received 18 August 2003; revised 25 February 2004; accepted 25 February 2004.

* Department of Pathology and Infectious Diseases, The Royal Veterinary College, University of London, North Mymms, Hatfield AL9 7TA, U.K.
(1977, 1981), Durette-Desset (1983), and Durette-Desset et al. (1994) considered the haemonchines as the sister group of the Trichostrongylinae Leiper, 1912, whereas Gibbons and Khalil (1982) and Lichtenfels (1987) postulated a basal position for the former nematodes relative to the Graphidiinae Travassos, 1937, Ostertagiinae (Skrjabin and Shult's, 1937), and Cooperiinae (Skrjabin and Shul'ts, 1937). Recent phylogenetic studies generally refute these earlier conclusions and are consistent in recognizing close affinities for Haemonchinae and Ostertagiinae.

Hoberg and Lichtenfels (1994) postulated the Haemonchinae and Ostertagiinae as monophyletic sister groups, a relationship that had not been proposed previously. This phylogenetic hypothesis was corroborated in studies by Durette-Desset et al. (1999) who proposed the "Haemonchidae" for these subfamilies, although systematics among the ostertagiines remain to be fully resolved, e.g., Durette-Desset et al. (1999) subsumed Graphidiinae within the Ostertagiinae. In contrast, Gouÿ de Bellocq et al. (2001) found the "ostertagiines" to be a paraphyletic assemblage basal to a monophyletic Haemonchinae as determined in analyses of partial sequences from $28 \mathrm{~S}$ ribosomal DNA (rDNA) for a limited number of exemplar species as representatives of generic level taxa. Alternatively, results by Chilton et al. (2001) based on limited comparisons of the ITS-2 region of rDNA among 21 species of trichostrongyloids were highly divergent with respect to these other studies; haemonchines (limited to $H$. contortus $+H$. placei) were considered as the putative sister group of the Cooperiinae or as basal trichostrongyles and consistent bootstrap support was lacking.

There has been no definitive or comprehensive phylogenetic study among the inclusive genera of the haemonchines (see Gibbons and Khalil, 1982; Durette-Desset, 1983, 1985). In their cladistic analysis and proposal for revision of the Trichostrongyloidea, Durette-Desset et al. (1999) clearly justified exclusion of Biogastranema Rohrbacher and Ehrenford, 1954 and Morguranema Yamaguti, 1941 from the Haemonchinae and recognized 5 genera. Comparative morphological data placed 
Boehmiella Gebauer, 1932 basal to Haemonchus and Ashworthius Le Roux, 1930 + Mecistocirrus Railliet and Henry, 1912; Leiperiatus Sandground, 1930 was not included in this analysis because of incomplete data (Durette-Desset et al., 1999). In addition, molecular-based analyses place Haemonchus basal to Ashworthius + Mecistocirrus (Gouÿ de Bellocq et al., 2001). Relative consistency and congruence in putative relationships among these sets of inclusive taxa contribute to the selection of appropriate out-groups for phylogenetic analyses of morphological characters among species of Haemonchus.

Comparative morphology remains a cornerstone for phylogenetic studies among genera and species of nematodes, particularly where synoptic collections are problematic and incomplete taxon sampling hinders the development of comprehensive databases sufficient for multilocus analyses across taxa often characterized by high diversity. Molecular-based comparisons among Haemonchus spp. have been limited to the development of diagnostic markers for species of economic importance in domestic Caprinae or Bovinae. These have focused on either 2-taxon, H. contortus and H. placei (e.g., Stevenson et al., 1995; Blouin et al., 1997), or 3-taxon statements such as comparative studies of $H$. contortus, $H$. placei, and $H$. similis (e.g., Zarlenga et al., 1994) or H. contortus, H. longistipes, and H. placei (e.g., Jacquiet et al., 1995). Although these species are clearly separated by divergence in either nuclear or mitochondrial loci, a synoptic molecular database does not yet exist to assess genetic diversity at either the intra- or interspecific levels or to provide a phylogenetic context for all currently valid species of Haemonchus.

In the current study, we developed a database for structural characters among the 12 known species of Haemonchus and appropriate out-groups. Our phylogenetic analyses were linked to a revision of Haemonchus, where specimens of all species of the genus were examined and redescribed where necessary (Gibbons, 1979; Lichtenfels et al., 2001, 2002). These studies led to the recognition and description of $H$. horaki and to the resurrection of $H$. okapiae, previously considered a synonym of $H$. contortus. In addition, the synonymy for other species, subspecies, and variants subsumed under $H$. contortus by Gibbons (1979) is accepted herein. Consistent with recent decisions, $H$. place $i$ is regarded as distinct from $H$. contortus on the basis of a combination of well-defined characters including the structure of the synlophe (Lichtenfels et al., 1986, 1988, 1994, 2002; Giudici et al., 1999; Lichtenfels and Pilitt, 2000; Hoberg et al., 2002). Geographic isolates that have been defined as subspecies for $H$. placei, including $H$. placei placei Giudici, Cabaret and Durette-Desset, 1999, H. placei africanus Giudici, Cabaret and Durette-Desset, 1999, and H. placei argentinensis Giudici, Cabaret and Durette-Desset, 1999, are subsumed within the nominal species in the context of our analyses.

Comparative morphological approaches promote the assessment of a large base of knowledge accumulated over the past $200 \mathrm{yr}$ and provide the opportunity to continually refine our understanding of structure and homology; ideally, the power of morphological and molecular data should be combined synergistically (e.g., Hoberg et al., 1999).

Phylogenetic hypotheses also provide the foundation for examining the history for host-parasite associations, historical ecology, and biogeography (Brooks and McLennan, 1991, 1993, 2002). Although Gibbons (1977) articulated hypotheses for African origins of Haemonchus and a role for domesticated ruminants in the global distributions for a restricted number of species, she did not explicitly evaluate these concepts. Apparent gaps in our knowledge have hindered elucidation of the coevolutionary and biogeographic associations for species of Haemonchus and their camelid and pecoran ruminant hosts and ultimately have challenged our understanding of host and geographic patterns of disease attributed to these nematodes. Beyond phylogenetic reconstruction among Haemonchus spp., in the current study, we attempt to integrate information from artiodactyl evolution (Gatesy and Arctander, 2000; Vrba and Schaller, 2000; Hassanin and Douzery, 2003) to develop hypotheses for coevolution and biogeography in this host-parasite assemblage. Among Haemonchus spp., a predictive classification, improved diagnostics, and an understanding of the relationships among parasites, hosts, and geographic regions contribute proactively in defining the potential for dissemination, expansion of populations, and emergence of these pathogenic nematodes globally across tropical and temperate latitudes and at the interface of managed and natural ecosystems.

\section{MATERIALS AND METHODS}

Phylogenetic analyses involved morphological characters among adult nematodes representing the 12 currently recognized species of Haemonchus. Characters were derived from study of specimens representing each of the species included in the analysis, along with data contained in original descriptions and redescriptions, e.g., Gibbons (1979), Giudici et al. (1999), Lichtenfels et al. (2001, 2002) (Table I). Standard methods for comparative morphology among Haemonchus spp. are outlined in Lichtenfels et al. (2001); methods for comparisons of the synlophe in Haemonchinae were derived primarily from Lichtenfels et al. (1994, 2001, 2002), Lichtenfels and Pilitt (2000), and Hoberg et al. (2002). General definitions for the structure of the synlophe are based on Durette-Desset (1983). Comparisons of patterns for bursal rays are based on concepts developed by Chabaud et al. (1970).

Characters included morphological attributes typical of male or female nematodes. Polarity was estimated on the basis of taxonomic or functional out-group comparisons as specified (Watrous and Wheeler, 1981; Maddison et al., 1984). Multiple out-groups were selected in reference to taxa basal to the Haemonchinae sensu Hoberg and Lichtenfels (1994) and Gouÿ de Bellocq et al. (2001) and include (1) Ostertagiinae sensu Hoberg and Lichtenfels (1994) as the putative sister group of the Haemonchinae, (2) Ostertagiinae sensu Gouÿ de Bellocq et al. (2001) as a paraphyletic assemblage of genera basal to Haemonchinae, and (3) basal taxa within "Haemonchidae," consistent with phylogenetic analyses by Durette-Desset et al. (1999) and a sister group relationship for Haemonchinae and Ostertagiinae (Table I). Ostertagiine genera included Teladorsagia Andreeva and Satubaldin, 1954 and Hyostrongylus Hall, 1921, with coding representing an estimate of ancestral states and a composite for these taxa. The putative sister group for Haemonchus, namely, species of Boehmiella Gebauer, 1932 constituted the sole Haemonchine out-group. Results of analyses by Chilton et al. (2001), because of their substantial divergence from the 3 phylogenetic studies cited above, were not used as a basis for out-group comparisons in the current study. In addition, specimens of related Haemonchinae were also examined in a comparative context (Table I).

We identified 25 attributes suitable for analysis and phylogenetic reconstruction among species of Haemonchus. Characters applied in higher level studies by Durette-Desset et al. (1999) were generally not appropriate at the level of universality represented in the current analyses. Several potentially continuous characters were included but only in instances where discrete numerical gaps or partitions could be recognized with respect to individual species or groups of Haemonchus (e.g., body length, number of ridges, length of spicules and gubernaculum). Descriptions for these binary and multistate characters are presented below and in a numerical matrix (Table II).

Parsimony analyses were conducted with PAUP $4.0 b 10$ for MacIntosh (see Swofford, 2001). Primary analyses used the following op- 
TABLE I. Specimens examined in a phylogenetic study of Haemonchus spp.

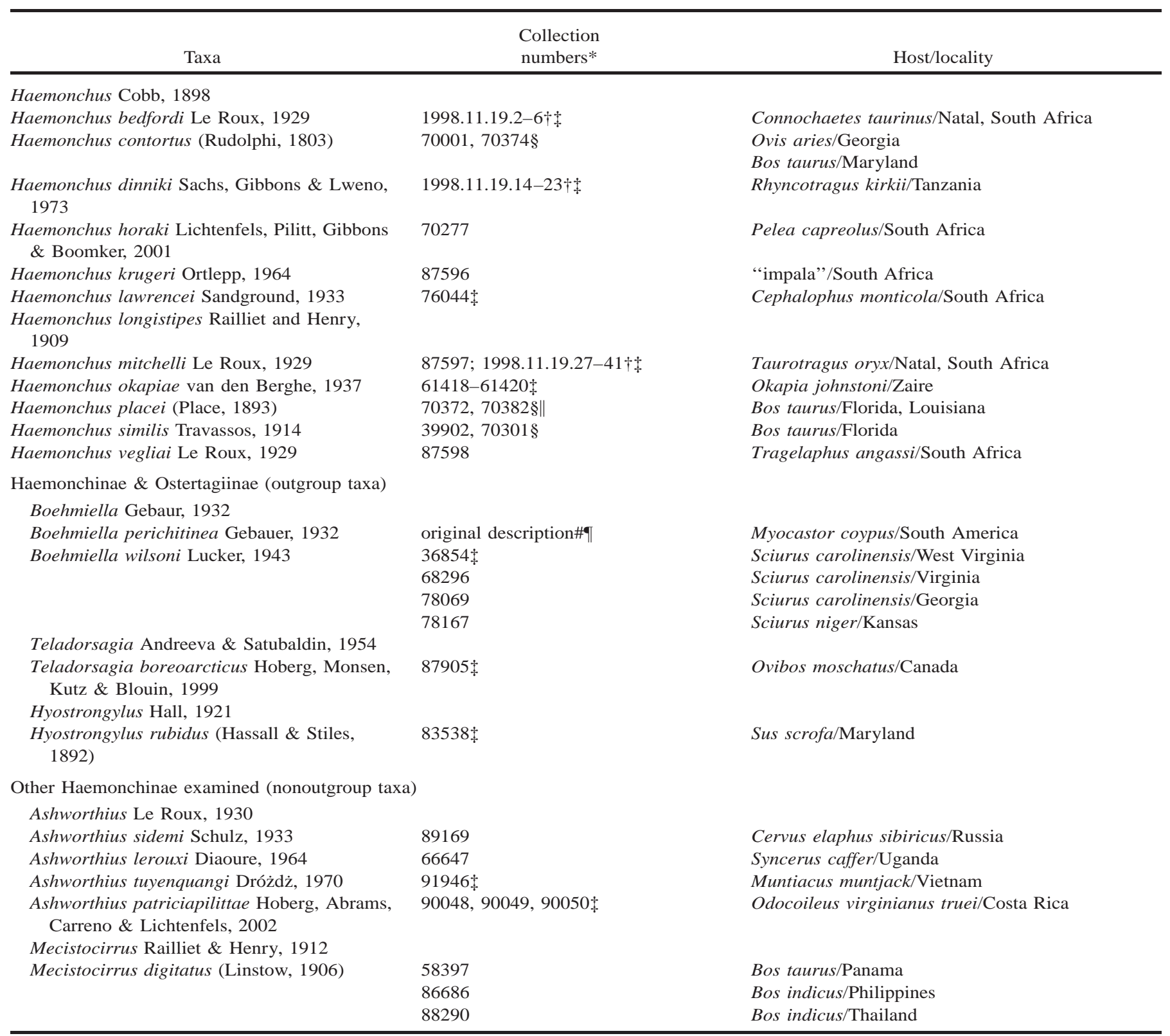

* Specimens held in the U.S. National Parasite Collection unless specified otherwise.

$\dagger$ The Natural History Museum, London, U.K.

$\$$ Type specimens.

\$ Additional specimens are listed in Lichtenfels et al. (1994).

\| Subspecies, including Haemonchus placei placei, Haemonchus placei africanus, and Haemonchus placei argentinensis, designated by Giudici et al. (1999) as geographically isolated and morphologically differentiated populations established historically in the past 500 years, are not explicitly included in the analysis. \# Gebauer (1932).

II Redescription by Durette-Desset and Sutton (1979).

tions: branch and bound, characters unordered, equal weights, addseq $=$ furthest, and accelerated transformation. Results are shown as phylogenetic tree(s) with associated statistics, including the length, consistency index (CI) excluding uninformative characters, and retention index (RI). In some secondary analyses in searching for the most parsimonious reconstructions, we also examined the influence of multistate characters as ordered and the inclusion or exclusion of specific characters on tree topology. Unambiguous characters were mapped directly onto the tree(s) for evaluation; the CI is given for specific characters of diagnostic importance. Further analyses included jackknife resampling as implemented in PAUP (1) 1,000 replicates, heuristic, random addi- tion sequence (10 replicates), holding 100 trees at each step, and branch swapping by tree bisection-reconnection and (2) 1,000 replicates, branch and bound; presentation as strict consensus trees. Bremer decay indices were calculated and used to examine support for putative relationships revealed in this study (Bremer, 1994). The results of these analyses form the basis for discussion about host associations and historical biogeography.

\section{Character descriptions}

Morphological attributes evaluated in this analysis include those of the synlophe characteristic of both males and females, male copulatory 
TABLE II. Character matrix for Haemonchus spp.

Characters 1-25

Species

$\begin{array}{lllllllllllllllllllllllll}1 & 2 & 3 & 4 & 5 & 6 & 7 & 8 & 9 & 1 & 1 & 1 & 1 & 1 & 1 & 1 & 1 & 1 & 1 & 2 & 2 & 2 & 2 & 2 & 2\end{array}$

Ostertagiinae*

Boehmiella $\dagger$

$\begin{array}{llllllllllllllll}0 & 1 & 2 & 3 & 4 & 5 & 6 & 7 & 8 & 9 & 0 & 1 & 2 & 3 & 4 & 5\end{array}$

Haemonchus bedfordi

Haemonchus contortus

Haemonchus dinniki

Haemonchus horaki

Haemonchus krugeri

Haemonchus lawrencei

Haemonchus longistipes

Haemonchus mitchelli

Haemonchus okapiae

Haemonchus placei

Haemonchus similis

Haemonchus vegliai

$\begin{array}{lllllllllllllllllllllllll}0 & 0 & 0 & 0 & 0 & 0 & 0 & 0 & 0 & 0 & 0 & 0 & 0 & 0 & 0 & 0 & 0 & 0 & 0 & 0 & 0 & 0 & 0 & 0 & 0 \\ 0 & 0 & 0 & 0 & 0 & 0 & 0 & 0 & 0 & 0 & 0 & 0 & 0 & 0 & 0 & 0 & 0 & 2 & 0 & 0 & 0 & 0 & 0 & 0 & 0 \\ 0 & 2 & 2 & 0 & 1 & 2 & 1 & 2 & 0 & 0 & 0 & 1 & 1 & 1 & 0 & 1 & 1 & 1 & 1 & 1 & 1 & 1 & 1 & 1 & 0 \\ 1 & 1 & 1 & 0 & 1 & 3 & 0 & 0 & 0 & 0 & 0 & 1 & 1 & 1 & 0 & 1 & 1 & 1 & 0 & 1 & 1 & 1 & 1 & 0 & 0 \\ 1 & 0 & 0 & 0 & 0 & 0 & 0 & 0 & 0 & 0 & 0 & 0 & 0 & 1 & 0 & 1 & 0 & 1 & 0 & 1 & 1 & 0 & 1 & 0 & 0 \\ 2 & 0 & 0 & 0 & 0 & 0 & 0 & 0 & 0 & 0 & 1 & 2 & 1 & 1 & 0 & 1 & 1 & 1 & 0 & 0 & 1 & 1 & 1 & 0 & 0 \\ 0 & 1 & 0 & 0 & 1 & 1 & 0 & 0 & 0 & 0 & 0 & 0 & 0 & 0 & 0 & 0 & 0 & 1 & 0 & 0 & 0 & 0 & 1 & 0 & 0 \\ 0 & 0 & 1 & 0 & 0 & 0 & 0 & 0 & 0 & 0 & 3 & 0 & 0 & 1 & 1 & 0 & 0 & 1 & 1 & 0 & 0 & 0 & 2 & 0 & 0 \\ 2 & 3 & 2 & 1 & 2 & 1 & 2 & 2 & 1 & 1 & 0 & 2 & 1 & 1 & 0 & 1 & 1 & 1 & 0 & 1 & 0 & 1 & 1 & 1 & 1 \\ 1 & 3 & 2 & 1 & 1 & 2 & 2 & 2 & 1 & 1 & 0 & 2 & 1 & 1 & 2 & 0 & 1 & 1 & 1 & 2 & 0 & 1 & 1 & 1 & 1 \\ 1 & 3 & 2 & 1 & 1 & 3 & 2 & 2 & 1 & 1 & ? & 1 & 1 & 1 & 2 & 1 & 1 & 1 & 1 & 0 & 1 & 1 & 1 & 1 & 1 \\ 1 & 2 & 2 & 0 & 1 & 3 & 2 & 1 & 0 & 0 & 0 & 1 & 1 & 1 & 0 & 0 & 1 & 1 & 0 & 1 & 1 & 1 & 1 & 0 & 0 \\ 0 & 2 & 2 & 1 & 1 & 2 & 2 & 2 & 0 & 0 & 0 & 0 & 1 & 1 & 0 & 1 & 0 & 1 & 0 & 1 & 1 & 1 & 1 & 1 & 1 \\ 1 & 3 & 2 & 1 & 1 & 2 & 2 & 2 & 2 & 1 & 0 & 1 & 1 & 1 & 2 & 0 & 1 & 1 & 1 & 2 & 0 & 1 & 1 & 1 & 1\end{array}$

* Outgroup, representing ancestral states for Teladorsagia and Hyostrongylus as a composite.

$\dagger$ Outgroup, including Boehmiella perichitinea and Boehmiella wilsoni.

structures, and the female tail. Characters were assessed by direct observation of male and female nematodes, and major comparisons of structural attributes among the species of Haemonchus have been summarized in a series of pertinent papers (Gibbons, 1979; Lichtenfels et al., 1994, 2001, 2002; Giudici et al., 1999; Lichtenfels and Pilitt, 2000; Hoberg et al., 2002). Binary and multistate characters are described below and are also summarized in a numerical data matrix (Table II).

1. Body length of males; 3 states: $0=$ small, about $10 \mathrm{~mm}$ or less; $1=$ medium, about $15 \mathrm{~mm} ; 2=$ large, about $20 \mathrm{~mm}$.

Characters 2-11. Synlophe. Cuticular ridge systems characteristic of haemonchines represent important diagnostic characters for resolution of generic and species level relationships and for identification (Lichtenfels et al., 1994; Lichtenfels and Pilitt, 2000; Hoberg et al., 2002). Consistent with a basal position within Haemonchinae, the synlophe of $B$. wilsoni terminates in the posterior two-thirds of the body in both males and females; definable lateral and dorsoventral ridges are present, lateral fields are narrowly spaced, and ridges are parallel throughout and of equal height (except for the smaller lateral) with a perpendicular orientation (E. P. Hoberg, J. R. Lichtenfels, and A. Abrams, unpubl data). These character states are consistent with the plesiomorphic condition for the synlophe within the subclade containing Haemonchinae + Ostertagiinae. (Hoberg and Lichtenfels, 1994); this interpretation is not altered if the Graphidiinae is subsumed within the Ostertagiinae as suggested by Durette-Desset et al. (1999). Consequently, further putative synapomorphies for crown haemonchine genera (Haemonchus, Ashworthius, and Mecistocirrus) include even spacing of ridges in the lateral and dorsoventral fields and loss of the lateral and the dorsoventral ridges.

Lichtenfels and Pilitt (2000) developed a general reference scheme for describing ridge systems among the crown genera of haemonchines. A system based on the numbers of ridges seen in a whole-body mount or in a transverse section of the body at the esophageal-intestinal junction (EIJ) and presence or absence and extent of sublateral, subventral, and subdorsal ridges provided a means for identification of species in Haemonchus, Ashworthius, and Mecistocirrus digitatus (Linstow, 1906). Modifications to this protocol by Hoberg et al. (2002) and Lichtenfels et al. (2002) involved more refined definition of sublateral ridge systems and the dorsal and ventral fields in relation to the position of the prominent sublateral cords, a set of criteria found to be phylogenetically informative in the current study.

2. Synlophe, number of ridges composing synlophe at level of EIJ; 4 states: $0=26$ ridges; $1=30$ ridges; $2=34$ ridges; $3=36$ or more (42 based on Lichtenfels et al. [2002]). This character was coded in reference to the functional out-group or basal species of Haemonchus as recognized in preliminary analyses (Watrous and Wheeler, 1981).

3. Synlophe, extent of ridges in males and females; 3 states: $0=$ extending length of entire body (including postvulvar in female); $1=$ termination near three-fourths of body length (prevulvar in female); 2 $=$ termination in anterior half of body.

4. Synlophe, posterior termination of first sublateral ridges; 2 states: $0=$ anterior to middle of synlophe length; $1=$ at or near posterior end of synlophe.

5. Synlophe, anterior origin of second sublateral ridges; 3 states: 0 $=$ absent; 1 = near level of cervical papillae; $2=$ substantially anterior to cervical papillae.

6. Synlophe, posterior termination of second sublateral ridges; 4 states: $0=$ absent; $1=$ at or near EIJ; $2=$ near midsynlophe; $3=$ near end of synlophe.

7. Synlophe, anterior origin of first subventral and subdorsal ridges; 3 states: $0=$ absent; $1=$ posterior half of esophageal region, lateral to 3 dorsal or ventral ridges; 2 = anterior half of esophageal region, lateral to 3 dorsal or ventral ridges.

8. Synlophe, posterior termination of first subventral and subdorsal ridges; 3 states: $0=$ absent; $1=$ midsynlophe; $2=$ end of synlophe.

9. Synlophe, anterior origin of second subventral and subdorsal ridges; 3 states: $0=$ absent; $1=$ at or near to EIJ; $2=$ significantly posterior to EIJ.

10. Synlophe, posterior termination of second subventral and subdorsal ridges; 2 states: $0=$ absent; $1=$ at or near end of synlophe.

11. Synlophe, height and thickness of ridges in lateral, dorsal, and ventral fields; 2 states: $0=$ lateral and sublateral ridges taller and thicker than dorsals and ventrals; 1 = all ridges nearly equal in thickness and height.

12. Males, spicules, total length; 3 states: $0=400 \mu \mathrm{m}$ or less; $1=$ $400-450 \mu \mathrm{m}$ or less; $2=500 \mu \mathrm{m}$ or more.

13. Spicule tips, symmetry; 2 states: $0=$ symmetric; $1=$ asymmetric.

14. Spicule tips, position of barbs in relation to distal tips; the usual condition is that a barb is present on each spicule tip; 2 states: $0=$ barb part of tips; 1 = separate from tips. The hoof-like structure described by Gibbons (1979) in specimens of $H$. krugeri viewed laterally is considered homologous with barbs that are typical among other members of the genus. The presence of a barb, irrespective of position at the tip or adjacent to the tip, is a constant and unique character for Haemonchus spp. and thus represents a synapomorphy for the genus.

15. Spicule tips, extra barbs; in some species the right spicule will have an extra barb, whereas in others, both spicules will have an extra barb; 3 states: $0=$ no extra barbs; $1=1$ barb on each spicule tip; $2=$ 1 barb on right spicule tip.

16. Gubernaculum, shape; 2 states: $0=$ broader anteriorly; $1=$ spindle shaped.

17. Gubernaculum, length; 2 states: $0=$ less than $200 \mu \mathrm{m} ; 1=$ greater than $200 \mu \mathrm{m}$. 
Characters 18-22. Bursa and dorsal ray. Durette-Desset et al. (1999) recognized asymmetry of the dorsal lobe as the sole synapomorphy for the genus but also regarded a similar structure in Boehmiella, the putative sister taxon for Haemonchus and remaining haemonchines, as a phylogenetically diagnostic character. In the phylogeny presented by Durette-Desset et al. (1999), and consistent with their character coding, they showed only 1 of 2 possible reconstructions for this attribute and did not extensively address this issue (see fig. 43, p. 1075). In either reconstruction, 2 steps are required (1) origin of asymmetry in the dorsal lobe and ray occurs independently in Boehmiella and Haemonchus (preferred by Durette-Desset et al., 1999) or (2) the alternative involves the origin of asymmetry in the dorsal lobe basal to Boehmiella and Haemonchus with later loss of asymmetry in the ancestor of Ashworthius + Mecistocirrus. The dorsal lobe and ray among Haemonchus spp. is strongly asymmetrical and differs considerably from Boehmiella on the basis of our study of type material. In contrast to the condition in Haemonchus, the dorsal ray is symmetrical and the lobe is not strongly defined relative to the bursa in B. wilsoni Lucker, 1943. Furthermore, in $B$. perichitinea Gebauer, 1932, although the ray could be regarded as weakly asymmetric, it is more accurately described as curved and the dorsal lobe is essentially absent or fused with the adjacent lobe of the bursa (see Gebauer, 1932; Durette-Desset and Sutton, 1979). Thus, both the plesiomorphic condition (symmetrical) and an autapomorphy (asymmetric and curved) are represented with respect to the dorsal ray among Boehmiella spp., and we would suggest that asymmetry in Haemonchus and the former genus may not be homologous. In the current study, we have coded the conditions in Haemonchus and Boehmiella as independent character states.

18. Bursa, dorsal ray, origin; 2 states: $0=$ symmetric (medial plane of body); 1 = asymmetric (to left of medial plane); 2 = weakly asymmetric and curved, consistent with Boehmiella.

19. Bursa, dorsal ray, shaft thickness; 2 states: $0=$ thin; $1=$ thick.

20. Bursa, dorsal ray, shaft shape; 3 states: $0=$ uniform thickness; 1 $=$ with median bulge; $2=$ thickened at base.

21. Bursa, dorsal ray, percentage of dorsal ray bifurcated; 2 states: 0 $=$ about $25-33 \% ; 1=40-50 \%$.

22. Bursa, dorsal ray, percentage of dorsal ray branches bifurcated; 2 states: $0=40-50 \% ; 1=20 \%$ or less.

23. Bursa, relative size of ventral (rays 2,3) and lateral rays (rays $4,5,6) ; 3$ states: $0=$ ventral rays smaller than lateral rays; $1=$ ventral and lateral rays nearly equal; 2 = ventral rays larger than laterals.

24. Tail shape of adult females; 2 states: $0=$ elongate, uneven tapering (ratio of length to greatest width 4.5-6); 1 = short cone (ratio of length to greatest width less than 4).

25. Tail length of adult females as percentage of body length; 2 states: $0=$ greater than $2 \% ; 1=$ less than $2 \%$.

\section{Host associations, coevolution, and biogeography}

Comparisons focused on the distribution of Haemonchus spp. among the Camelidae and pecoran ruminants including the Antilocapridae, Giraffidae, Cervidae, and all subfamilies and tribes of the Bovidae, as diagnosed in phylogenetic studies by Gatesy et al. (1997), Gatesy and Arctander (2000), Vrba and Schaller (2000), and Hassanin and Douzery (2003). The host phylogeny in the current study is an informal supertree that was constructed from explicit phylogenetic hypotheses derived from both comparative morphology and molecular sequences. Each of these independent hypotheses supports the major clades of the Artiodactyla, but topology among the hypotheses may vary; thus, the tree applied in our study is an estimate or approximation of artiodactyl relationships and represents a rough consensus. Among the Bovidae, we used the fully resolved hypothesis from Vrba and Schaller (2000) that includes each of the recognized subfamilies and tribes.

The concept of "preferred" host as articulated by Le Jambre (1983), Boomker (1990), and Amarante et al. (1997) was applied to interpretations of historical relationships for Haemonchus spp., where putative core or "primary" versus satellite or "secondary" hosts, host groups, or associations reflect a conservative interpretation of data for prevalence and abundance of each species of nematode; data primarily from Horak (1980) and Boomker (1990). The terms core and satellite are consistent with usage proposed by Bush et al. (1997), and with respect to the current study, this emphasizes the linkage between phylogenetic history and ecological structure. In this context, terminology developed by Horak (1980) and Boomker (1990) is also appropriate where such core associations have been identified as "definitive" when they involve relationships of putative evolutionary duration. In contrast, satellite associations would be termed "occasional" and "accidental" and are indicative of ephemeral or contemporary linkages where nematodes are acquired from other artiodactyls that are required for the maintenance of source faunas. Justification for this terminology and a number of apparent caveats are outlined and discussed in greater detail in subsequent sections. Data for biogeography and parasite distribution among pecoran ruminants were derived from the primary literature, including Gibbons (1979), Horak (1980), Boomker (1990), and a comprehensive compilation of published host records (L. M. Gibbons, unpubl. data).

Complementary comparative approaches were used to assess the congruence of host and parasite phylogenies. Initially a "tanglegram" was developed to explicitly show the linkages between core hosts and parasites and to demonstrate how this fauna has been structured by processes of cospeciation or colonization. Concurrently, terminals (species) of the parasite tree were numbered to facilitate mapping onto the host phylogeny. A process of reciprocal parsimony mapping was used to examine the history for widespread species of Haemonchus in their artiodactyl and pecoran ruminant hosts. Parasites, including putative core and satellite species, were mapped directly onto the independent host phylogeny that represents current hypotheses about relationships for the artiodactyls (Gatesy et al., 1997; Gatesy and Arctander, 2000; Vrba and Schaller, 2000; and Hassanin and Douzery, 2003). Host and geographic distributions were also mapped and optimized onto the phylogeny for Haemonchus spp. to develop and examine hypotheses for historical relationships. Independent matrices specifying host and geographic distributions (not shown) were written in MacClade 4.0, and distributional data as characters were mapped and optimized onto the parasite phylogeny (see D. R. Maddison and W. P. Maddison, 2000).

\section{RESULTS}

\section{Phylogeny for Haemonchus spp.}

Primary analysis resulted in 1 most parsimonious tree (MPT) (60 steps; $\mathrm{CI}=0.67, \mathrm{RI}=0.80$; excluding phylogenetically uninformative characters, $\mathrm{CI}=0.65)$, consistent with Haemonchus as an inclusive group (Fig. 1). Secondary analyses, with multistate characters ordered, also resulted in 1 MPT (not shown) found to be 4 steps longer but of identical topology (64 steps; $\mathrm{CI}=0.63$; excluding uninformative characters, $\mathrm{CI}=$ 0.61). Monophyly for Haemonchus was diagnosed by 3 unequivocal synapomorphies, including the asymmetric origin of the dorsal ray (character 18) and relative size of the ventral rays (character 23); in addition the presence of a barb on each spicule tip (see discussion under character 14) is a synapomorphy for all of Haemonchus. This suite of phylogenetically diagnostic characters was determined in reference to out-group and sister taxa among haemonchines and ostertagiines; additional comparisons included taxa within the inclusive Haemonchinae (Ashworthius LeRoux, 1930; and Mecistocirrus, Railliet and Henry, 1912).

The distribution of unambiguous characters in the primary analysis has been mapped and optimized onto the phylogenetic tree representing putative relationships among the 12 species of Haemonchus (Fig. 1). Among 25 characters, 23 were phylogenetically informative; homoplasy was evident among 11 characters. Bremer decay indices and the topology of the strict consensus tree resulting from jackknife resampling showed consistent structure (Fig. 2).

\section{Character evolution and relationships among Haemonchus spp.}

Although homoplasy was extensive for some characters, consistent trends were evident in evolution among a suite of attri- 


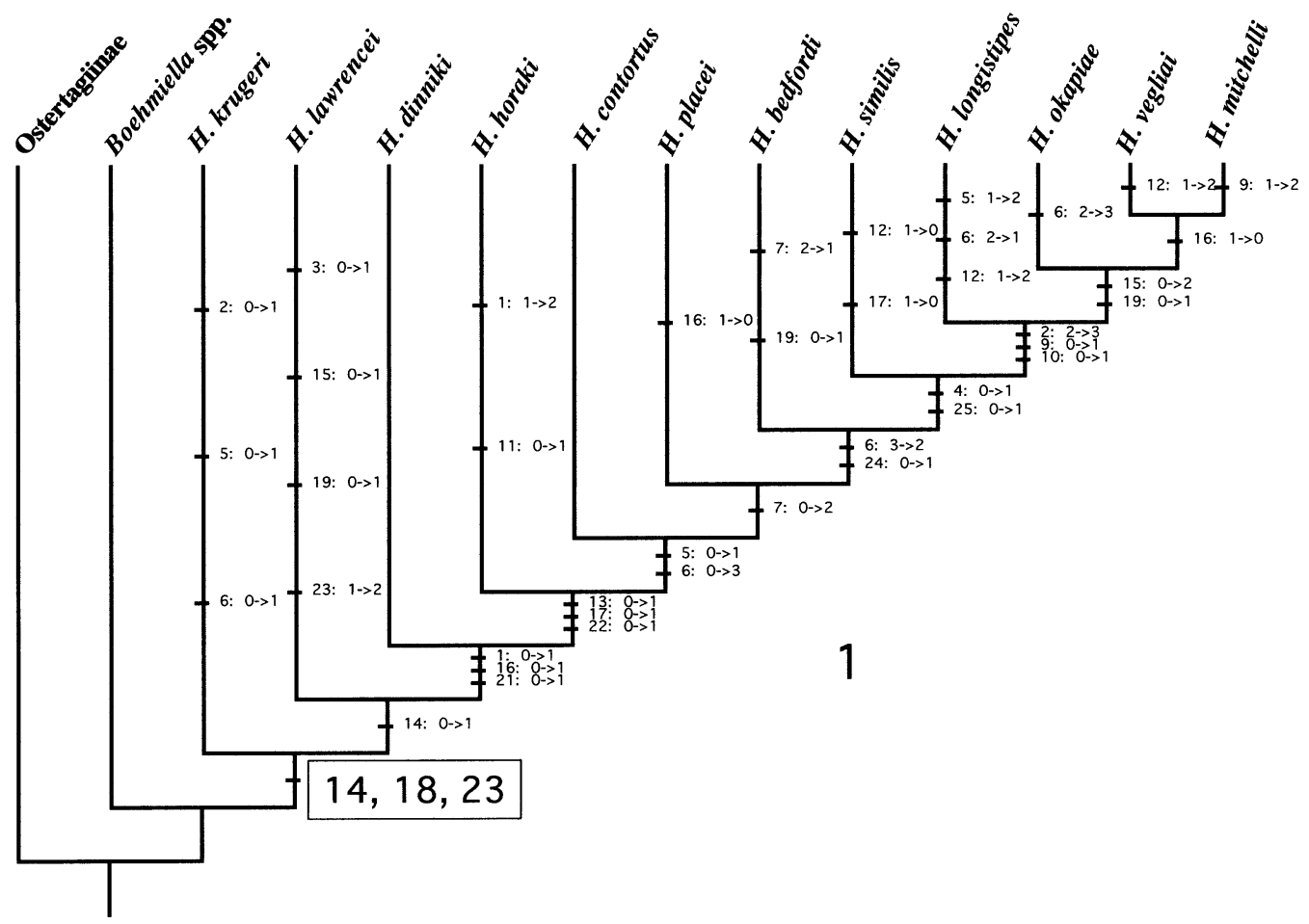

FIGURE 1. Phylogenetic tree depicting hypotheses for relationships of species in Haemonchus Cobb, 1898. Shown is the single most parsimonious tree derived from analysis of 25 morphological characters (60 steps; $\mathrm{CI}=0.67, \mathrm{RI}=0.80$; excluding phylogenetically uninformative characters, $\mathrm{CI}=0.65)$. Unambiguous characters were mapped onto the tree; 3 unequivocal synapomorphies (characters $14,18,23)$ diagnose monophyly for Haemonchus relative to the out-groups represented by Boehmiella spp. and a composite based on ostertagiine genera.

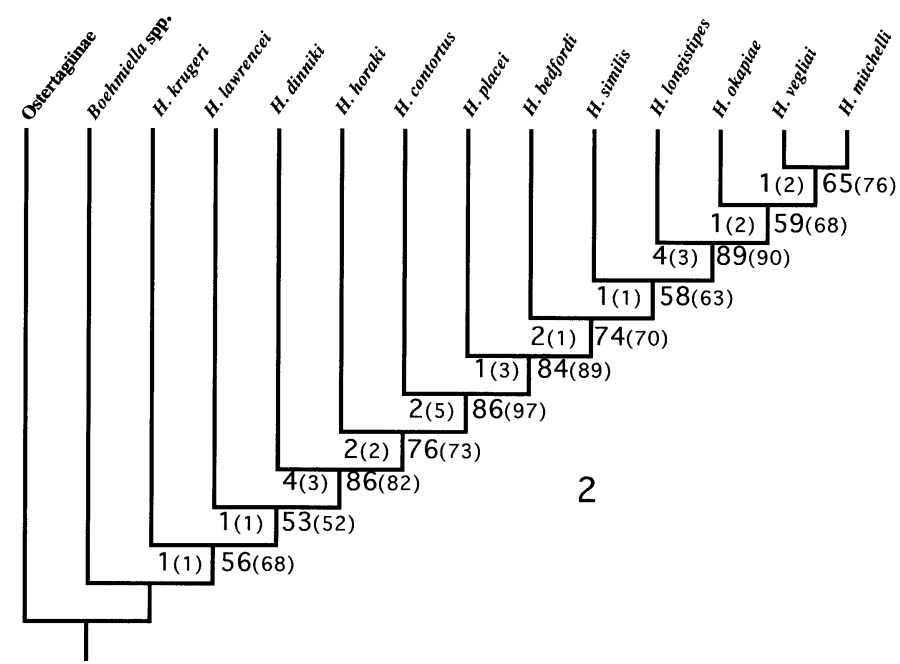

FIGURE 2. Phylogenetic tree depicting hypothesis for relationshps of species in Haemonchus Cobb, 1898. Tree support was explored by jackknife resampling (values to the right of respective nodes) and calculation of Bremer decay indices (values to the left). Jackknife resampling for the tree shown was implemented in PAUP with 1,000 replicates, heuristic search, random addition sequence (10 replicates), holding 100 trees at each step, and branch swapping by TBR. The strict consensus tree resulting from jackknife resampling was identical to that in the primary analysis. Values shown in parentheses represent alternative analyses in which multistate characters were ordered. butes including the numbers of ridges (character 2; CI $=0.75$ ); extent of the synlophe (character 3; CI $=0.67$ ); and structure of the spicule tips (characters 13-15; CI $=1.0$ ), dorsal ray (character 22; CI $=1.0$ ), and female tail (characters 24-25; CI $=1.0$ ). In addition, these attributes diagnose relationships for groups of species within Haemonchus.

Considering the synlophe, a general trend from a low (26) to a high (42) number of ridges at the level of EIJ is well defined; addition of ridges occurs in the sublateral, subdorsal, and subventral fields. The 26-ridge system is postulated as plesiomorphic and occurs in $H$. lawrencei, $H$. dinniki, and $H$. horaki; 30 ridges characterize the basal $H$. krugeri and $H$. contortus; 34 ridges are found in $H$. placei, $H$. similis, and $H$. bedfordi; and 42-ridge systems are a putative synapomorphy for the crown species, $H$. longistipes, $H$. okapiae, $H$. mitchelli, and $H$. vegliai. The synlophe is typically complete and extends the entire length of the body among basal species of Haemonchus (excluding $H$. lawrencei and $H$. contortus) but is reduced among crown species (starting with $\mathrm{H}$. placei), where the ridge systems terminate in the anterior half of the body in males and females. In addition, the absolute extent posteriad for the sublateral ridge systems remains relatively constant (character 4, $\mathrm{CI}=1.0$; and character $6, \mathrm{CI}=0.60$ ), whereas surrounding ridges become diminished in length among crown species above $H$. similis.

The structure of the spicules and copulatory bursa of males further diagnose relationships. Symmetric spicule tips (character 13) are characteristic of basal species (H. krugeri-H. hor$a k i$, whereas increasing asymmetry is diagnostic for crown 


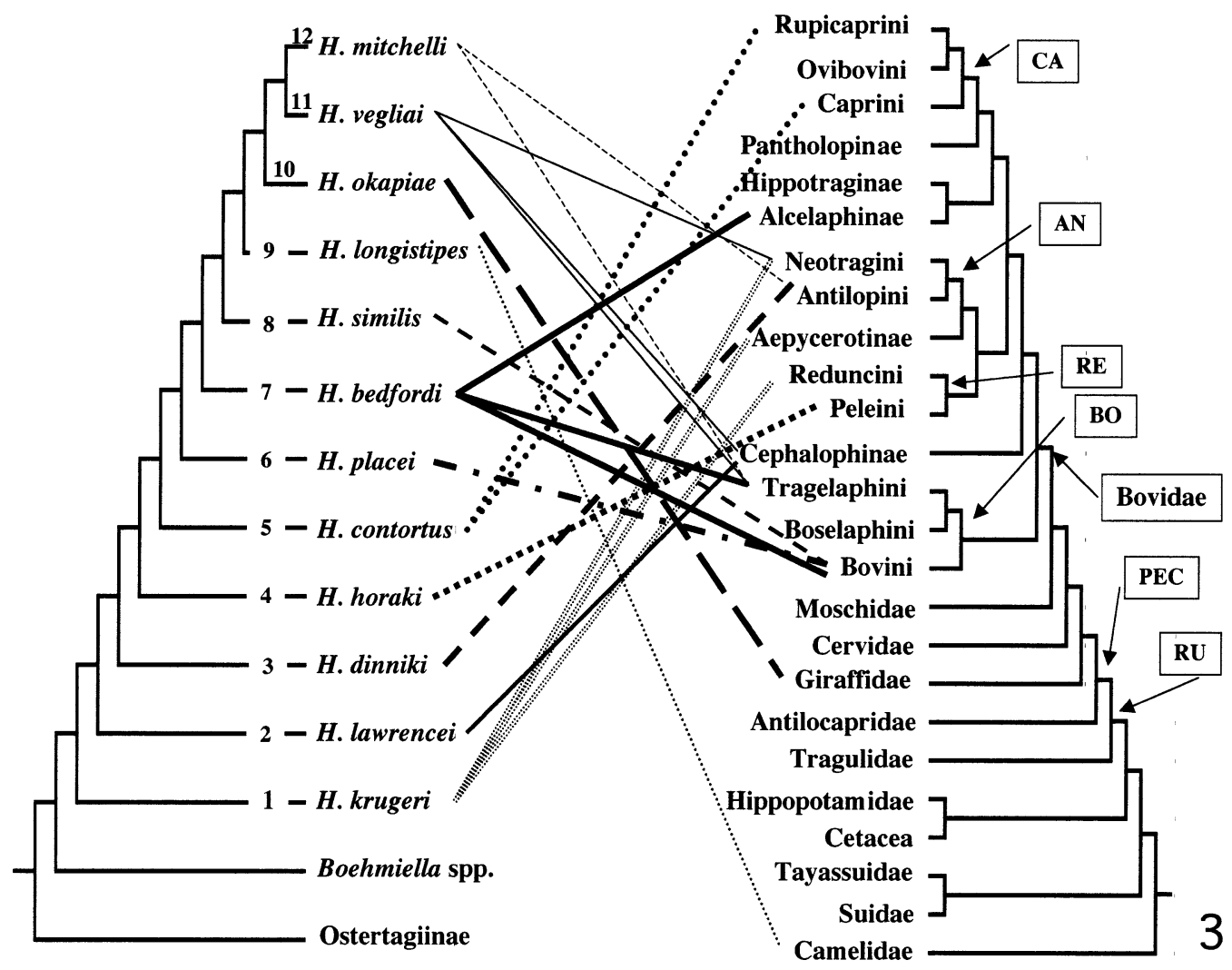

FIGURE 3. Direct comparison of phylogenetic hypotheses for Haemonchus spp. and artiodactyl host groups including the Camelidae and Pecora. Linkages depicted among parasites and hosts show putative primary or core associations for respective species of Haemonchus; secondary or satellite associations are not shown (Tables III, IV). Terminal taxa of the parasite phylogeny are sequentially numbered to facilitate reciprocal mapping onto the host phylogeny (Fig. 4). Host relationships are based on phylogenetic hypotheses for the Pecora and other artiodactyls (Gatesy et al., 1997; Vrba and Schaller, 2000; Gatesy and Arctander, 2000; and Hassanin and Douzery, 2003). Note that for basal species of Haemonchus core associations are primarily represented among antelopes including Cephalophini, Reduncini, Peleini, Antilopini, and Neotragini (Tables III, IV). In contrast, for crown species of Haemonchus, core hosts are typically found among basal artiodactyls such as Camelidae, or basal Pecora such as Giraffidae, or among the Bovini and Tragelaphini. Labeling of the host tree is consistent with Table IV: RU, Ruminantia; PEC, Pecora; BO, Bovinae; RE, Reduncinae; AN, Antilopinae; and CA, Caprinae.

species of Haemonchus. Irrespective of symmetry, the separation of the barb from the distal tip of each spicule (character 14) is a synapomorphy for all Haemonchus, excluding the basal H. krugeri. In addition, the presence of an extra barb (character 15 ) on the right spicule is a synapomorphy for $H$. okapiae, $H$. mitchelli, and $H$. vegliai; the presence of an extra barb on both the right and left spicules is an autapomoprhy for H. lawrencei. Among basal species, H. krugeri-H. dinniki, the bifurcation of the dorsal ray is placed near $25-33 \%$ from the distal end. Remaining species, above $H$. horaki are diagnosed by a ray bifurcation near $40-50 \%$.

Characters among females contributed to resolution of relationships for Haemonchus spp., including the shape (character 24) and relative size (character 25) of the tail. A cone shaped tail is a putative synapomorphy for crown species above $H$. bedfordi, whereas an elongate, tapering tail is the plesiomoprhic condition, typical of most species of Haemonchus. Furthermore, there is a trend for reduction in the relative length of the tail with respect to total body length, such that crown species including $H$. similis are diagnosed by short tails representing $<2 \%$ of the body.

\section{Parasite-host coevolution and historical biogeography}

Species of Haemonchus are parasites among camelids and pecoran ruminants representing 4 families and in general the distribution of single species involves a wide array of hosts with few exceptions (Fig. 3; Tables III, IV). Substantial incongruence is evident between the independent host phylogeny that represents current hypotheses about relationships for the artiodactyls (Gatesy et al., 1997; Gatesy and Arctander, 2000; Vrba and Schaller, 2000; Hassanin and Douzery, 2003) and the phylogenetic hypothesis for species of Haemonchus (Figs. 3-5). Incongruence is apparent in comparing host and parasite cladograms (Fig. 3) by reciprocal mapping of species codes for parasites directly onto the host phylogeny (Fig. 4) and of hosts onto the parasite tree (Fig. 5). A history of diversification driven primarily by host-switching is postulated for Haemonchus among the pecorans.

A prolonged history of colonization is indicated by the distribution of basal species of Haemonchus, e.g., H. krugeri, H. lawrenci, $H$. dinniki, and $H$. horaki, that occur in core associations with crown genera and species of grazing and browsing 
TABLE III. Distribution of species of Haemonchus, showing putative core and satellite associations for nematodes among pecoran ruminants and camelids on the basis of parasites in naturally infected hosts.

Species of

Host Haemonchus*

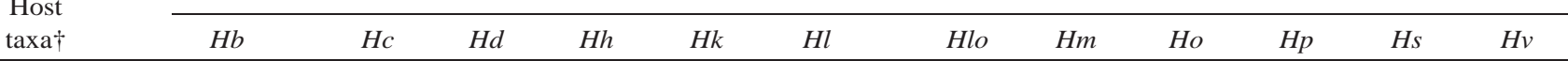

Camelidae

Camelus

Vicugna

Lama

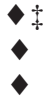

Cervidae

Alces

Blastocerus

Capreolus

Cervus

Dama

Mazama

Odocoileus

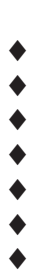

Antilocapridae

Antilocapra

Giraffidae

Giraffa

Okapia

$\checkmark$

Bovidae: Bovinae

Bovini

Bison
Bos
Bubalis
Syncerus

Tragelaphini

Taurotragus

Tragelaphus

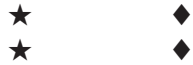

Bovidae: Cephalophinae: Cephalophini

Cephalophus

Sylvicapra

Bovidae: Reduncinae

Peleini

Pelea

Reduncini

Kobus
Redunca

Bovidae: Aepycerotinae: Aepycerotini Aepyceros

Bovidae: Antilopinae

Antilopini

Antilope

Antidorcas

Gazella

Neotragini

Neotragus

Oreotragus

Ourebia

Raphicerus

Rhyncotragus

Bovidae: Alcelaphinae: Alcelaphini

Alcelaphus

Connochaetes

Damaliscus

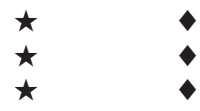

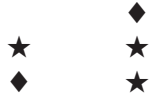

$\star$

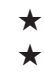

$\star$ 
TABLE III. Continued.

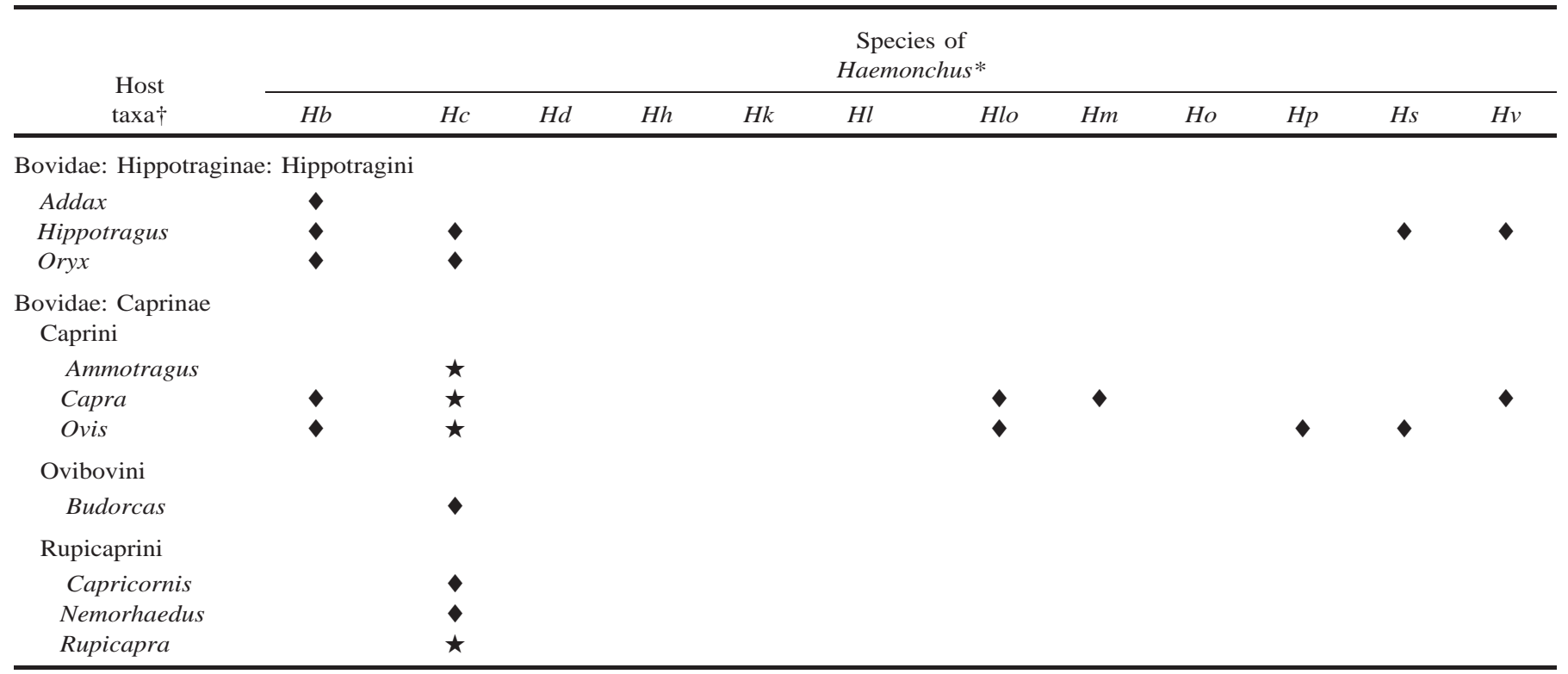

* Abbreviations for species of Haemonchus: Hb, H. bedfordi; Hc, H. contortus; Hd, H. dinniki; Hh, H. horaki; Hk, H. krugeri; Hl, H. lawrencei; Hlo, H. longistipes; Hm, H. mitchelli; Ho, H. okapiae; $H p, H$. placei; $H s, H$. similis; $H v, H$. vegliai.

$\dagger$ Host taxonomy in approximate phylogenetic order is based on Gatesy et al. (1997), Gatesy and Arctander (2000), and Vrba and Schaller (2000).

$\ddagger \star$ Indicates putative satellite or secondary host or host group usually ephemeral associations.

$\S$ Indicates putative core or primary host or host group on the basis of estimates of prevalence and abundance.

antelopes in sub-Saharan Africa (Figs. 3-5; Table IV). Primary host associations for $H$. contortus involve Caprinae, including both wild and domestic caprines, but ancestral associations for this species are likely linked to antelopes. There is a broad cosmopolitan range for $H$. contortus coinciding with sheep and goats, but parasitism among a diverse assemblage of secondary or satellite host groups is particularly evident (Figs. 4, 5; Tables III, IV). In contrast, crown species of Haemonchus, e.g., $H$. place,$H$. bedfordi, $H$. similis, $H$. mitchelli, and $H$. vegliai, have dominant core associations among the Bovinae (either Bovini or Tragelaphini) but rarely in antelopes (Cephalophini, Antilopini, Neotragini, and Alcelaphini), whereas H. longistipes and H. okapiae occur, respectively, among Camelidae and basal pecorans such as Giraffidae. Satellite associations, which represent widespread distributions, i.e., postspeciation host-switching, for most species of Haemonchus are maintained by source communities in antelopes and caprines or among Bovini and Tragelaphini in Africa.

The dichotomy of basal parasites occurring among crown hosts and crown parasites among relatively basal hosts reveals a temporal incompatibility or discontinuity in the distribution of Haemonchus among artiodactyls and the development of core associations. Ancestral hosts may be represented among the Reduncinae, Aepycerotinae, Antilopinae, and Cephalophinae. Basal diversification is associated with a number of tribes, genera, and species of antelopes, and a minimum of 7 evolutionary events (by colonization) involving species of Haemonchus are recognized (Figs. 3-5). Among these basal species, $H$. lawrencei in Cephalophus and H. horaki in Pelea capreolus are apparently host specific. Subsequent diversification among core hosts involves a minimum of 16 evolutionary events including colonization of Caprini and Rupicaprini (H. contortus), "backcolonization" and peripheral isolates speciation in Bovinae (in
Bovini: H. placei, $H$. bedfordi, and $H$. similis), a postspeciation host-switch to Tragelaphini ( $H$. bedfordi), back-colonization to Camelidae (H. longistipes), colonization of Giraffidae with postspeciation host-switching (or host speciation in the absence of parasite speciation) between Giraffa and Okapia (H. okapiae), colonization and peripheral isolates speciation in Tragelaphini (H. mitchelli and $H$. vegliai), and putative postspeciation host-switching to Alcelaphini $(H$. bedfordi), Cephalophini $(H$. vegliai), Antilopini (H. mitchelli), and Neotragini (H. mitchelli and $H$. vegliai). There is only limited coevolutionary structure in these core associations relative to phylogenetic history for hosts and parasites (Figs. 3-5).

Most species of Haemonchus are associated with wild pecorans, and only $H$. contortus, H. placei, $H$. similis, and $H$. longistipes occur in core associations among domesticated artiodactyls (Figs. 4, 5; Table III). Notably, these are also the only species of Haemonchus with distributions that extend beyond Africa in their respective caprine, bovine, and camelid hosts. Satellite associations among Cervidae and Antilocapridae in the Nearctic, Camelidae and Cervidae in the Neotropics, and Cervidae in the Palearctic apparently coincide with contemporary or temporally shallow historical host-switching from domestic ruminants, linked to anthropogenically driven geographic translocations and introductions (Fig. 5; Table IV). Consequently, biogeography and host distribution appear compatible with an African origin for Haemonchus, basal diversification driven by colonization among grazing and browsing antelopes with limited cospeciation, and subsequently a complex history of hostswitching to the Caprinae, Bovinae, Camelidae, and Giraffidae and among other pecorans involving both core and satellite associations (Figs. 4, 5; Table IV).

Mapping of core host groups directly onto the parasite phylogeny further reinforces the concept of colonization as a sub- 
TABLE IV. Geographic distributions and putative primary and secondary host associations for species of Haemonchus among Camelidae and Pecora.

\begin{tabular}{|c|c|c|c|}
\hline \multirow[b]{2}{*}{ Species } & \multirow[b]{2}{*}{$\begin{array}{l}\text { Geographic } \\
\text { distribution }\end{array}$} & \multicolumn{2}{|r|}{$\begin{array}{l}\text { Associations with } \\
\text { host groups* }\end{array}$} \\
\hline & & $\begin{array}{c}\text { Core } \\
\text { (Primary) }\end{array}$ & $\begin{array}{c}\text { Satellite } \\
\text { (Secondary) }\end{array}$ \\
\hline Haemonchus bedfordi & Africa, sub-Saharan & Al, Bo & Ae, An, Ca, Gi, Hi, Re \\
\hline Haemonchus contortus $\ddagger$ & Africa/Cosmopolitan $\dagger$ & $\mathrm{Ca}$ & Ae, Al, An, Ant, Bo, Cam, Cer, Gi, Hi, Re \\
\hline Haemonchus dinniki & Africa, sub-Saharan & An & $\mathrm{Ae}$ \\
\hline Haemonchus horaki & Africa, sub-Saharan & $\operatorname{Re}$ & Al \\
\hline Haemonchus krugeri & Africa, sub-Saharan & Ae, An, Re & - \\
\hline Haemonchus lawrencei & Africa, sub-Saharan & $\mathrm{Ce}$ & $\mathrm{Ae}$ \\
\hline Haemonchus longistipes $\$$ & Africa, N \& sub-Saharan/Eurasia/India & Cam & An, Bo, Ca \\
\hline Haemonchus mitchelli & Africa, sub-Saharan & Bo, An & $\mathrm{Ae}, \mathrm{Ca}$ \\
\hline Haemonchus okapiae & Africa, sub-Saharan & $\mathrm{Gi}$ & - \\
\hline Haemonchus placei & Africa/Cosmopolitan $\dagger$ & Bo & Ae, Ant, Ca, Cer \\
\hline Haemonchus similis末 & Africa/Cosmopolitan $\dagger$ & Bo & Ae, Al, Ca, Cer, Hi \\
\hline Haemonchus vegliai & Africa, sub-Saharan & $\mathrm{An}, \mathrm{Bo}, \mathrm{Ce}$ & $\mathrm{Ae}, \mathrm{Hi}, \mathrm{Re}$ \\
\hline
\end{tabular}

* Host groups: Ae, Aepycerotinae; Al, Alcelaphinae; An, Antilopinae (contains Antilopini and Neotragini); Ant, Antilocapridae; Bo, Bovinae (contains Bovini and Tragelaphini; Boselaphini are not recognized as hosts); Cam, Camelidae; Ca, Caprinae (contains Caprini, Ovibovini, and Rupicaprini); Ce, Cephalophinae; Cer, Cervidae; Gi, Giraffidae; Hi, Hippotraginae; Re, Reduncinae (contains Peleini and Reduncini).

$\dagger$ Cosmopolitan: Europe, North America, South America, Australia, India, Eurasia, AustralAsia, representing geographic distributions linked to anthropogenic translocation and introduction of hosts and parasites with secondary colonization of endemic ruminants.

† Economically important parasite in domestic ruminants.

stantial driver for diversification (Fig. 5). Also apparent is the influence of domestic ruminants on the now cosmopolitan distributions for some species of Haemonchus. Only those species associated with domesticated Caprini and Bovini have distributions in the Nearctic and Neotropics and occur in satellite associations among cervids and camelids (Figs. 4, 5).

\section{DISCUSSION}

\section{Haemonchus and the trichostrongyles}

Phylogenetic reconstruction among the trichostrongyles has diagnosed a sister group relationship between the monophyletic Haemonchinae and Ostertagiinae (Hoberg and Lichtenfels, 1994; Durette-Desset et al., 1999). Haemonchinae as a natural taxon is diagnosed by a long common trunk and distal divergence for rays 2 and 3 of the copulatory bursa (Hoberg and Lichtenfels, 1994; Durette-Desset et al., 1999) and presence of prominent sublateral hypodermal cords (Lichtenfels and Wergin, 1994). Inclusive to the haemonchines, Boehmiella is basal to Haemonchus and Ashworthius + Mecistocirrus (DuretteDesset et al., 1999). Among these generic level taxa, unique patterns of the synlophe exclude Boehmiella and further diagnose the crown group containing Haemonchus, Ashworthius, and Mecistocirrus (Hoberg and Lichtenfels, 1994; Lichtenfels and Pilitt, 2000; Hoberg et al., 2002). Hierarchical relationships were the foundation for selection of out-groups (Table I) and served to identify putative transformation series for structural characters among the 12 species of Haemonchus.

\section{Diagnosing generic and species relationships-evolution of the bursa and synlophe}

On the basis of analyses of a suite of morphological attributes (Table II), monophyly for the genus Haemonchus was not refuted in the current study. Monophyly for Haemonchus was diagnosed by 3 unequivocal synapomorphies, including the presence of a single barb on each spicule tip, asymmetric origin of the dorsal ray, and relative size of the ventral rays. Parsimony analysis resulted in 1 MPT (Fig. 1); analyses with multistate characters unordered or ordered yielded identical topologies supported by jackknife resampling and Bremer decay indices (Fig. 2). There has been no previous hypothesis for species level relationships in Haemonchus based on datasets from comparative morphology or sequences from nuclear and mitochondrial loci. Relationships revealed in the current study appear to be consistent, relatively robust, and are not influenced when representatives of the Ostertagiinae are applied as the sole out-group in estimation of ancestral states for characters among species of Haemonchus.

Apparent asymmetry of the dorsal lobe, with origin shifted to the left, is a synapomorphy only for Haemonchus spp. in a comparative context with either Boehmiella spp. or the ostertagiines. Consistent with conclusions and interpretations of Durette-Desset et al. (1999) and the current study, we suggest independent origins for the structure of the dorsal ray in Boehmiella and Haemonchus, respectively. Thus, monophyly for Haemonchus is clearly established on the basis of comparative morphology and molecular studies by Gouÿ de Bellocq et al. (2001) who reported strong bootstrap and Bremer support for the relationships of Haemonchus and Ashworthius + Mecistocirrus.

Among species of Haemonchus, a phylogenetically diagnostic trend for addition of ridges in the sublateral, subdorsal, and subventral fields is evident (Fig. 1). Although Lichtenfels et al. (2002) were uncertain about the exact number of ridges in specimens of $H$. vegliai (in excess of 36 , with up to 42?), results of our phylogenetic study would predict a 42-ridge system in this species (Figs. 1, 2). Clearly, characters of the synlophe are significant and phylogenetically informative among trichostron- 


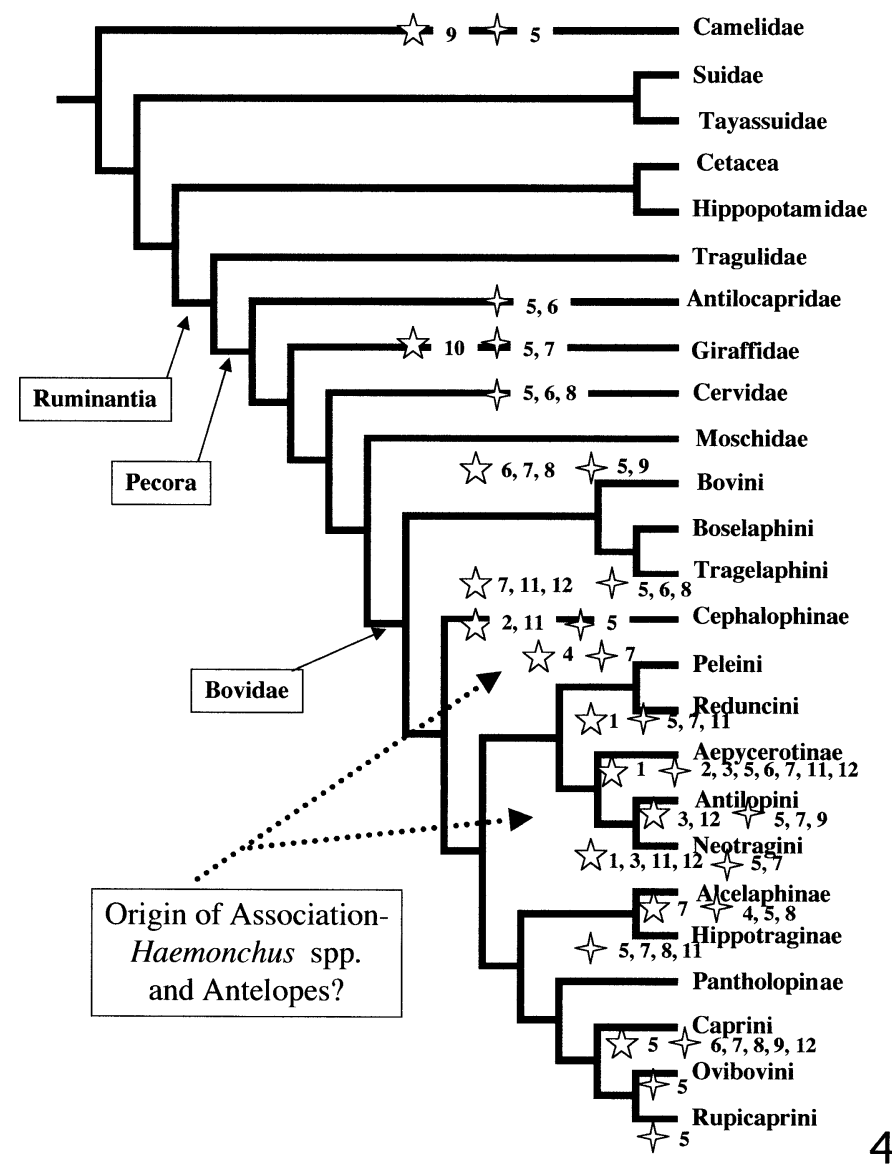

Figure 4. Phylogeny for the Artiodactyla and Pecora based on hypotheses presented by Gatesy et al. (1997), Vrba and Schaller (2000), Gatesy and Arctander (2000), and Hassanin and Douzery (2003). Species codes denoting parasite taxa (1-12), consistent with Figure 3, are

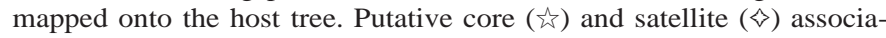
tions are indicated for species of Haemonchus and their pecoran hosts. The initial association of Haemonchus and pecorans appears among tribes, genera, and species of Reduncinae, Aepycerotinae, Antilopinae, and Cephalophinae in Africa; basal species of Haemonchus have diversified among relatively crown antelopes. Subsequent diversification involved extensive back-colonization among pecorans and to the $\mathrm{Ca}$ melidae. Satellite associations are maintained by source or core faunas in grazing and browsing antelopes, Caprinae or Bovinae. Substantial incongruence with the established host phylogeny is evident (see Fig. 3 ) and is indicative of a pervasive history of colonization as a driver of parasite diversification. Postspeciation colonization as the basis for both core and satellite associations has resulted in the apparently broad diversity of artiodactyl hosts recognized for Haemonchus spp. Only core associations are considered to be of evolutionary significance or of importance for maintenance of parasites within specific geographic zones. In this respect, core faunas among antelopes, Caprinae, or some Bovinae represent the sources for satellite associations for Haemonchus among sympatric ruminants in the context of ecosystems and communities.

gyles at the generic and species levels as demonstrated in the current study and in higher level analyses (Hoberg and Lichtenfels, 1994).

Skrjabin et al. (1954) and Durette-Desset (1964) were among the first to recognize the significance of the synlophe for nematode taxonomy and systematics in respective studies of Citellinema Hall, 1916, and the heligmosomes. Standard criteria were developed for describing the structure of ridge systems (number, orientation, gradient) on the basis of observations of transverse sections usually prepared from the midbody region of adult nematodes (Durette-Desset, 1983). Subsequently, a series of studies at the U.S. National Parasite Collection led to the articulation of general reference schemes to develop synoptic descriptions of ridge systems in the context of comparative studies among a diversity of trichostrongyloids including genera and species within the Nematodirinae, Cooperiinae, Ostertagiinae, and Haemonchinae (e.g., among others, Lichtenfels, 1977; Lichtenfels and Pilitt, 1983, 2000; Lichtenfels et al., 1986, 1994; Lichtenfels and Hoberg, 1993). Under these protocols, a comprehensive understanding of the synlophe was not limited to observations from sectioned specimens but integrated detailed descriptions of cervical and whole-body patterns and the distribution of ridges in the lateral and dorsoventral fields, with standard data summarizing numbers, gradients, and orientations. Consequently, a wealth of data are available for resolution of relationships at discrete levels of universality among the trichostrongyloids.

In this context, phylogenetic analyses based on comparative morphology among the trichostrongyloids have either included (Hoberg and Lichtenfels, 1994) or excluded (Durette-Desset et al., 1999) characters of the synlophe. Durette-Desset et al. (1999) considered only presence and absence of ridges and found this to be a character plagued with extensive levels of homoplasy because of putative patterns of independent loss among nematode taxa of this group, including the Trichostrongylinae and Libyostrongylinae. Such a conclusion led DuretteDesset et al. (1999) to eliminate consideration of any synlophe characters in their phylogenetic reconstructions of the trichostrongyloids. In contrast, at higher levels among the subfamilies of the trichostrongyles (Hoberg and Lichtenfels, 1994), and among genera and species in the current study, an array of characters of the synlophe have been found to be phylogenetically informative. Thus, we would advocate using all characters available for phylogenetic reconstruction and for estimation of relationships among taxa.

\section{Parasite-host coevolution and historical biogeography}

Collectively, species of Haemonchus are characterized by widespread distributions among their artiodactyl hosts (Table III). Multiple species often occur in mixed infections in single hosts (e.g., Boomker, 1990); for example, 8 of 12 species of Haemonchus have been reported in Aepyceros melampus from sub-Saharan Africa. Generally, species of Haemonchus are also widely shared within a related assemblage of Camelidae and Pecora including Giraffidae, Bovinae, Cephalophinae, Aepycerotinae, Reduncinae, Antilopinae, Alcelaphinae, Hippotraginae, and Caprinae from sub-Saharan Africa, but only 3 species have broad cosmopolitan distributions in domesticated hosts (Tables III, IV). Consequently, resolution of host relationships, biogeography, and the history of diversification for species of Haemonchus has often been considered intractable because of a general absence of host specificity and the often exceptionally broad distributions recognized for many of these nematodes among artiodactyls (Table III). In the absence of apparent host specificity, except for $H$. lawrencei and $H$. horaki, the development of historical coevolutionary hypotheses was reduced to a confusing morass of linkages among species of Haemonchus and a diverse assemblage of pecoran hosts (e.g., Fig. 3). Further 


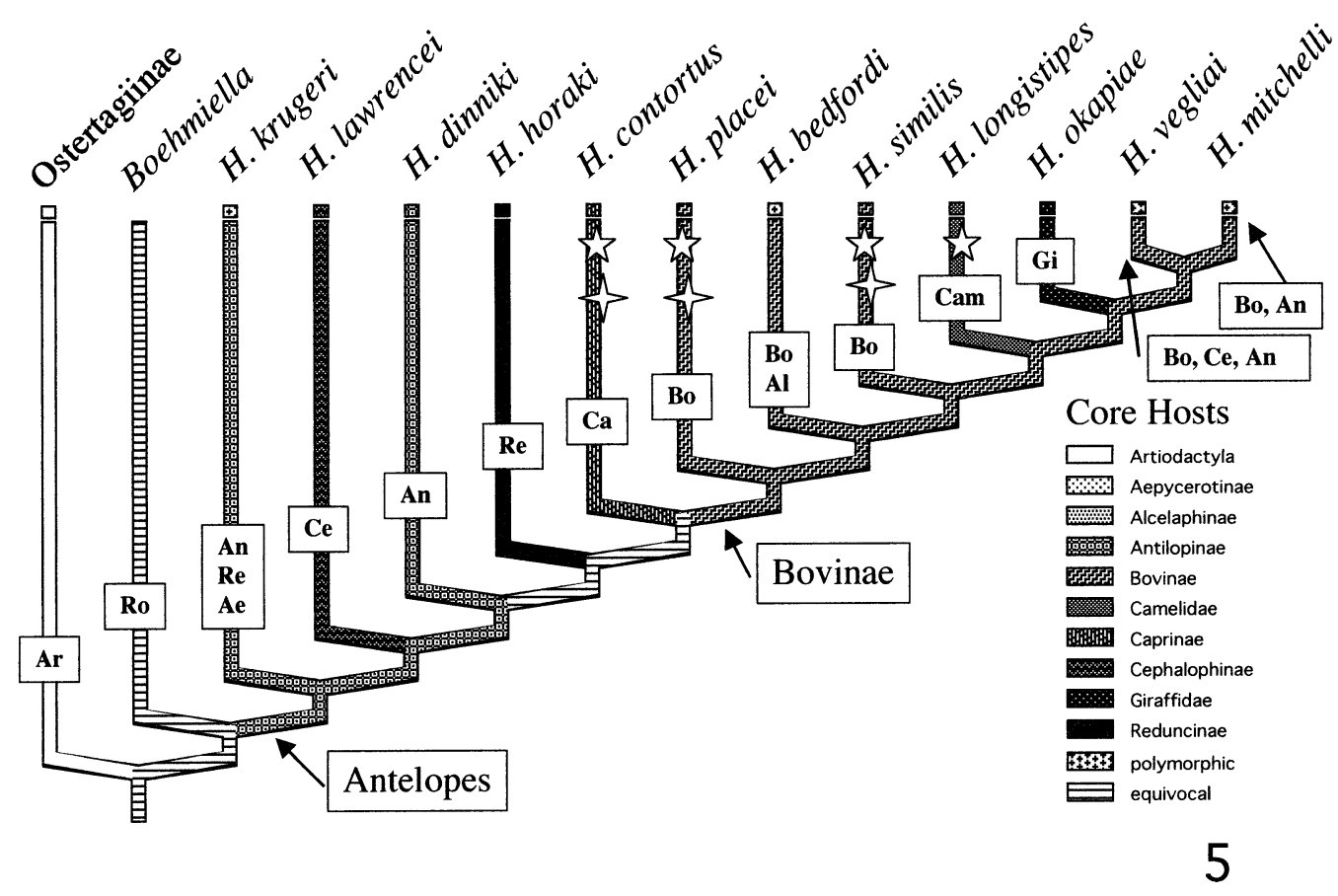

FIGURE 5. Phylogeny for Haemonchus spp. with distribution of primary or core hosts mapped and optimized onto the parasite tree by MacClade 4.0 (Maddison and Maddison, 2000). Data for host distributions are derived from Tables III, IV. Relationships for hosts and parasites are consistent with basal diversification among antelopes and a subsequent history of host-switching to Bovinae, basal Pecora, and Camelidae. Core associations in domesticated hosts (㧒) are generally geographically widespread, with $H$. contortus, $H$. placei, and $H$. similis having essentially cosmopolitan distributions linked to global translocation and introduction of sheep and cattle since the 1500s. Satellite associations (今) for these species, particularly among Cervidae and Camelidae in the Neotropics and Cervidae, Antilocapridae, and possibly wild Caprinae in the Nearctic have been a consequence of introductions and exchange of parasites at historical interfaces for managed and natural ecosystems. Such distributions are emblematic of the overriding significance of anthropogenic factors as determinants of the global distributions of pathogenic parasites in domestic and wild ruminants. Abbreviations for host groups are consistent with Table IV: Ar, Artiodactyla; Ae, Aepycerotinae; Al, Alcelaphinae; An, Antilopinae; Bo, Bovinae; Cam, Camelidae; Ca, Caprinae; Ce, Cephalophinae; Gi, Giraffidae; Re, Reduncinae; Ro, Rodentia.

chaos was introduced by assumptions about the significance of domesticated hosts in the broader diversification of the genus.

In the current study, we attempt to integrate phylogeny and ecology and have focused on the concept of core (primary, preferred, or definitive) versus satellite (secondary, occasional, or accidental) associations to develop testable hypotheses for the history of diversification among Haemonchus and artiodactyls. These ideas about host associations are not novel, having been articulated on the basis of detailed observations of the behavior, prevalence, and abundance of a number of Haemonchus spp. in wild and domesticated hosts (Horak, 1980; Le Jambre, 1983; Boomker, 1990; Amarante et al., 1997). Such concepts, however, have not been applied previously to elucidating the evolutionary history for Haemonchus. Thus, we identify core associations as those of substantial evolutionary duration, being indicative of historical and potentially prolonged associations for parasites and hosts within an assemblage (Boomker, 1990). These are the associations that involve core host species or host groups in which fitness for respective species of parasites is maximized and in which parasites occur often at predictable levels of prevalence and abundance within definable or circumscribed biogeographic zones (Table IV). In contrast, satellite associations are ephemeral and represent contemporary or short-term linkages where nematodes have been acquired from sympatric hosts that maintain core or source faunas (Boomker, 1990). The observation is that parasites in such satellite associations are reproductively unsuccessful and do not contribute to the long-term maintenance of a regional fauna and thus in an evolutionary sense are not significant.

Beyond identifying core associations (Fig. 3; Table IV), understanding host and geographic distribution remains complex and may be further confounded in the current study of Haemonchus by 4 major factors (1) great morphological homogeneity among most species of Haemonchus indicates the potential for incorrect or superficial identifications of morphologically similar species, even those in separate genera (Gibbons, 1977, 1979; Lichtenfels et al., 1994; Lichtenfels and Pilitt, 2000; Hoberg et al., 2002), (2) potential for currently unrecognized cryptic species among the extensive array of synonyms, e.g., H. okapiae resurrected by Lichtenfels et al. (2002), (3) unrecognized limits for species level morphological variation, e.g., description of $H$. horaki based on the "long spicule" form of $H$. contortus, Lichtenfels et al. (2001), and (4) the continued need for synoptic epizootiological data to refine our understanding of prevalence, abundance, and the distribution of Haemonchus among core versus satellite hosts.

Some species' records may not be reliable because until recently separation of specimens of $H$. placei and $H$. contortus on the basis of comparative morphology was problematic (Lichtenfels et al., 1986, 1988, 1994; Jacquiet et al., 1997); thus, many reports of $H$. contortus, particularly among Bovinae may represent $H$. placei. There may also be some misidentification of $H$. mitchelli and $H$. okapiae and problems with the separation of $H$. horaki and $H$. contortus, particularly in the context of 
older records (Lichtenfels et al., 2001, 2002). These instances, however, are unlikely to have influenced the identification of core hosts or associations. In addition, it is possible to confuse $H$. contortus with Ashworthius patriciapilittae Hoberg, Abrams, Carreno and Lichtenfels, 2002, a haemonchine described based on material in $O$. virginianus from Costa Rica (Hoberg et al., 2002). Finally, we continue to have scant information on the abomasal parasite fauna of endemic cervids in South America (Almeida, 1933, 1935; Diaz et al., 1977; Vicente et al., 1997).

These factors may contribute to incorrect assessments of the diversity and associations of particular species of Haemonchus in specific artiodactyl hosts or host groups. Furthermore, uneven sampling effort relative to host species and geographic regions may also bias our current understanding of the distribution of Haemonchus spp., particularly in Eurasia and South America, and also in Africa (Gibbons, 1977; Boomker, 1990). Continued survey and inventory of sufficient scope and depth is necessary to develop a refined appreciation for the structure of associations for parasites and hosts. Concurrently, application of molecular-based systematics would be expected to provide an increasingly fine-scale understanding of species diversity, population genetic structure, phylogenetic history, and biogeography (Blouin et al., 1995; Hoberg et al., 1999; Brooks and Hoberg, 2000). Outlining these caveats, however, contributes to a conservative process of discovery in elucidating hypotheses for the coevolutionary and biogeographic history among species of Haemonchus.

Phylogenetic information for hosts and parasites is the foundation for the discovery of the extent of coevolutionary processes, e.g., cospeciation, coadaptation, colonization, and extinction, involved in diversification and as determinants of the history and structure of faunal assemblages (Brooks, 1979, 1981; for pertinent reviews on methods see Brooks and McLennan, 1991, 2002, 2003; Dowling, 2002; Page, 2002; Dowling et al., 2003; Siddall and Perkins, 2003; Brooks et al., 2004). This integrative approach fosters a broader comprehension of biodiversity and is also strongly bolstered by inclusion of data regarding regional history and historical biogeography for recognized hosts of an assemblage (Hoberg, 1997a; Brooks and Hoberg, 2000).

Evidence for a history of cospeciation or association by descent among species of Haemonchus and Camelidae or the Pecora was not revealed (Figs. 3-5). Substantial incongruence is apparent in direct comparisons of parasite and host phylogenies (Fig. 3) and is corroborated in analyses involving reciprocal mapping (Figs. 4, 5). In this assemblage, incongruence is consistent with an extensive history for host-switching in the evolution of Haemonchus (Figs. 3-5). Notably, basal species of Haemonchus have core associations only with grazing and browsing antelopes and Caprinae and are limited to relatively crown pecorans. In contrast, crown species of Haemonchus are linked to Camelidae, Giraffidae, and Bovinae (Bovini and Tragelaphini), which represent basal artiodactyls or Pecora. Thus, basal parasite species are distributed among crown hosts, and crown parasites are distributed among basal hosts reflecting a temporal discontinuity in core associations.

Distributions among core hosts further reflect initial colonization of antelopes, sequential colonization as a driver of diversification for Haemonchus in Cephalophinae, Reduncini, Peleini, Aepycerotinae, Antilopini, and Neotragini, and a history of back-colonization to Bovinae and Giraffidae in sub-Saharan Africa and to Camelidae in North Africa (Figs. 4, 5). It is suggested that the ancestor of $H$. contortus was distributed first in antelopes and secondarily became associated with Caprini (Fig. 5). Maintenance of diverse but ephemeral satellite associations reflect contemporary colonization or postspeciation hostswitching within assemblages of sympatric pecorans where the continuity of particular parasite species is linked to reproductive success and dissemination in the context of their core associations. Core associations in grazing and browsing antelopes, caprines, camelids, and bovines serve as source faunas for respective species of Haemonchus that may be widespread in an array of satellite hosts.

Pecorans are a monophyletic group of artiodactyls with origins in Eurasia about 45 million years before present (MYBP), and constituent families are recognized by the late Oligocene between 29 and 24 MYBP, whereas basal divergence among subfamilies and tribes, particularly Bovinae, Antilopinae, and Caprinae, had occurred by the early to middle Miocene or about 22-15 MYBP (Gentry, 2000; Hassanin and Douzery, 2003). Dates of the first appearance in Africa for representatives of already established subfamilies and tribes that had initially diversified in Eurasia, however, were generally later, starting in the middle Miocene and extending into the Pliocene from 16 to 3 MYBP (Vrba, 1985, 1995; Gentry, 2000; Vrba and Schaller, 2000; Hassanin and Douzery, 2003). The net direction of range expansion was into Africa. These observations and the limited distribution of Haemonchus outside of Africa (Tables III, IV), and particularly Eurasia, would refute a hypothesis for association by descent among parasites and hosts. There is no compelling empirical evidence to suggest that absence of Haemonchus spp. or core associations among Antilocapridae, Cervidae, Moschidae, Boselaphini, Hippotraginae, Pantholopinae, and among some caprines can be linked to secondary extinction events during the diversification of this fauna (Fig. 4). In this regard, it is necessary to distinguish time and region of origin (which may be early) and date of first appearance and duration in Africa. Thus, a phylogenetically old group such as the Camelidae, or pecorans such as Bovinae, could arrive in Africa relatively late and subsequent to the appearance of a phylogenetically younger group such as the Antilopini; phylogenetic structure in this event is decoupled from spatial and temporal relationships for historical biogeography of artiodactyls in Africa. Consequently, differential arrival times in Africa for respective artiodactyl taxa may have served as a primary driver for sequential host-switching by Haemonchus among antelopes, Caprini, Bovini, Camelidae, Giraffidae, and Tragelaphini.

Although the exact relationships among the antelopes require further resolution (compare Gatesy and Arctander, 2000; Vrba and Schaller, 2000; Hassanin and Douzery, 2003), Antilopini, Neotragini, Aepycerotinae, Reduncini, Peleini, and Cephalophini are unequivocally core hosts for the basal species of Haemonchus (Figs. 4-5); these tribes may represent a rapid radiation 20-18 MYBP. Antilopini has the longest continuous duration in Africa and is first recognized in the abundant fossil record about 14 MYBP (Vrba, 1985, 1995; Vrba and Schaller, 2000). Neotragini and Cephalophini appear about 12 MYBP, Reduncini and Aepycerotinae at 6-7 MYBP, and Peleini at 3 MYBP; these tribes may also have African origins (Vrba, 1985). 
Diversification in these groups and Bovinae coincided with expansion of African savannahs over the late Miocene and Pliocene. In contrast, the Caprini have 2 appearances in Africa, the first at 14 MYBP and the second at about 3-2 MYBP, but both were followed by extinctions (Vrba, 1985, 1995). Compared with the antelopes, the Giraffidae and Bovinae were late immigrants to Africa, and species of Giraffa and Okapia are known from Africa by about 6 MYBP but shared a common ancestor in the early Miocene about 19 MYBP. Among the Bovinae, the Tragelaphini appear in Africa about 7 MYBP and Bovini about 5 MYBP.

Although the pecorans have an extended and diverse history in Africa, camelids were relatively recent immigrants to the continent. Camelidae are among the basal artiodactyls, having originated in North America during the early Tertiary and with a first appearance in Africa during the Pliocene (Kurtén and Anderson, 1980). Camelus dromedarius, the core host for $H$. longistipes, was domesticated in Arabia about $6 \mathrm{KYBP}$, but wild populations are considered to have occurred in North Africa and the Middle East before domestication. Dispersal of the dromedary with nomadic cultures appears to have been a significant influence on the distribution of $H$. longstipes into southern Asia and would account for satellite associations in domestic caprines and Bos (Figs. 4, 5; Table III). Absence of core associations for Haemonchus among South American camelids is consistent with host-switch to Camelus in North Africa.

The chronology established for the appearance of bovids, giraffids, and camelids in Africa appears compatible with a history of sequential host-switching. Back-colonization from antelopes to Bovinae and Camelidae would be linked to periods of range expansion into Africa for respective host taxa. The distribution of Haemonchus is further consistent with initial formation of core parasite-host associations having developed after major diversification among pecorans and their later arrival in subSaharan Africa. Thus, there is no core association recognized for species of Haemonchus in the Antilocapridae, Moschidae, and Cervidae. The absence of Haemonchus among the Boselaphini, which had a duration in Africa over 15 million years only to go extinct at the Miocene-Pliocene boundary (Vrba, 1985, 1995), may also be explained by the temporal scale and duration of parasite-host associations; representatives of this pecoran group now survive in Eurasia. In addition, Antilope cervicapre, Pantholopini represented by the monotypic Pantholops hodgsoni (chiru or Tibetan gazelle), and other wild pecorans from Eurasia are not found in core associations for species of Haemonchus. Apparent absence of an endemic fauna in the Nearctic and Neotropical regions further suggests that climatic conditions and an arctic-adapted fauna characteristic of Beringia were unsuitable for range expansion of Haemonchus with caprine bovids from the Palearctic during the late Pliocene and Pleistocene (Hoberg et al., 1999, 2003). Such associations are a clear demonstration of the geographically restricted history for Haemonchus in sub-Saharan Africa.

Ecological perturbation linked to climate variation in Africa may have had an impact on host-parasite associations during pulses of bovid radiation and faunal turnover that characterized periods of the middle Miocene (14-15 MYBP) and late Miocene (7-5 MYBP) (Vrba, 1985; Gentry, 2000; Vrba and Schaller, 2000), depending on the timing of the initial association between Haemonchus and the antelopes. Faunal turnover during the late Pliocene (3-2.5 MYBP) may also have had an influence on contemporary distributions of Haemonchus among antelopes (Vrba, 1985, 1995; Vrba and Schaller, 2000). Environmental change has been linked to fluctuating climate leading to extensive development of grasslands after 2.5 MYBP. Large herbivores represented by grazers among the Antilopini, Neotragini, Cephalophinae, Alcelaphinae, Hippotragini, Peleini, and Reduncini attained a dominant status (Vrba, 1985; Vrba and Schaller, 2000). Thus, patterns of range expansion and immigration and faunal associations linked to habitat structure established among a diverse assemblage of pecorans in Africa would have constituted the determinants and ecological potential for host-switching and radiation for Haemonchus.

A restricted regional distribution in Africa for basal species of Haemonchus in antelopes indicates (1) Haemonchus did not originate in association with basal artiodactyls or pecorans in Eurasia, (2) Haemonchus was not brought into Africa by range expansion of either Camelidae or Pecora, (3) host groups including Bovinae, Camelidae, and Giraffidae arrived sequentially dispersing from Eurasia into Africa where it is postulated they acquired Haemonchus from antelopes (driving further diversification by host-switching), and (4) global distributions for a limited number of species of Haemonchus were attained only during recent historical times and did not for example involve range expansion across Beringia into the Nearctic. In general, these conclusions do not refute the brief conceptual framework established by Gibbons (1977) for the origin and later radiation among species of Haemonchus. In addition, new hypotheses for the radiation among species of Haemonchus provide strong empirical corroboration for the concepts and mechanisms, but not specific historical details, of "host capture" in diversification among some Trichostrongyloidea as originally outlined by Chabaud $(1965,1971)$ and Durette-Desset (1985).

Alternatively, Durette-Desset et al. (1999) postulated radiation of haemonchines among artiodactyls of Africa, the western Palearctic, and Eurasia during the upper Miocene. Collectively, with respect to radiation of crown haemonchines (Haemonchus, Ashworthius, and Mecistocirrus), such a scenario is consistent with overall distributions for hosts and parasites. In a restricted sense, for species of Haemonchus among artiodactyls, however, the results of the current study would refute a biogeographic history linked to the western Palearctic or Eurasia. It should be noted that the study outlined by Durette-Desset et al. (1999) was neither designed to examine details of species level relationships within Haemonchus nor was a robust methodology applied to historical analyses. Such contentions thus remain to be tested in the context of species level hypotheses for all inclusive host and parasite taxa.

\section{Host domestication: sheep cattle and the haemonchines}

The putative history for Haemonchus in Africa pecorans, and the otherwise limited diversity observed in the Palearctic, Eurasia, and the Indian subcontinent, Australia, and the Western Hemisphere (Figs. 4, 5; Table III) indicates a significant role for domesticated artiodactyls in the contemporary distributions of representatives of this genus (Gibbons, 1977). Core associations for Haemonchus in domesticated bovids are generally geographically widespread, with $H$. contortus, $H$. placei, and $H$. similis having essentially global distributions linked to a per- 
vasive history for translocation and introduction of sheep and cattle since the 1500s (e.g., Hoberg, 1997b, Giudici et al., 1999; Hoberg et al., 2001). Satellite associations for these species, particularly among Cervidae and Camelidae in the Neotropics and Cervidae, Antilocapridae, and possibly wild Caprinae in the Nearctic, have been a consequence of introductions and exchange of parasites at historical interfaces for managed and natural ecosystems. For example, reports of $H$. contortus in the Nearctic involve a diverse array of ungulate hosts, including domestic Ovis aries, Capra hircus, Bos taurus, and Llama glama, semicaptive Addax nasomaculatus, Antilope cervicapre, Hippotragus niger, and Oryx biesa, exotic cervids such as Cervus dama and C. axis, and wild Antilocapra americanus, Ovis canadensis, Bison bison, Alces alces, and Odocoileus spp. (Hoberg et al., 2001). In addition, H. contortus, H. placei, and $H$. similis only acquired cervid hosts after translocation from Africa to Eurasia, North America, South America, Australia, and New Zealand; no other species of Haemonchus is known in Cervidae (Fig. 5; Tables III, IV). Overall, such distributions are emblematic of the continued significance of anthropogenic factors as determinants of the global distributions for pathogenic parasites in domestic and wild ruminants. In these instances, and specifically for $H$. contortus, $H$. placei, and $H$. similis, the diversity of secondary hosts has been acquired by colonization in near contemporary settings after introduction and dissemination in new ecological situations and a breakdown in geographic isolating mechanisms (see also Hoberg, 1997b).

Absence of an endemic fauna for Haemonchus in the Western Hemisphere is in contrast to several other nematode groups in ruminants, notably genera and species of the Ostertagiinae, $\mathrm{Ne}$ matodirinae, and possibly haemonchines in the genus Ashworthius (Hoberg et al., 2001, 2002). Significantly, the Haemonchus fauna in the Western Hemisphere does not appear to be a mosaic of endemic and introduced species as demonstrated for some ostertagiines such as Teladorsagia and Ostertagia (Hoberg et al., 1999, 2001). All species of Haemonchus in North America and the Western Hemisphere have apparently been introduced, and there was no endemic species circulating before European contact.

Domestic stock serve as source populations for Haemonchus in wild ruminants from North America, and the northern extent for distribution among these parasites may be currently limited by climate across temperate and boreal latitudes in the Nearctic (these concepts may apply to other regional settings outside of Africa). Consequently, habitat perturbation associated with global climate change, analogous to the historical linkage of climate fluctuation and environmental change in Africa during the Miocene and Pliocene, could have a substantial impact on the distribution of Haemonchus in North America and globally. Parallels are also to be expected or predicted for expanding distributions for M. digitatus (Linstow, 1906) in South and Central America concomitant with global warming.

A defining role has been identified for anthropogenic factors, specifically translocations and introductions with hosts, in determining the distribution of Haemonchus in domesticated sheep and cattle. In addition, Giudici et al. (1999) outlined hypotheses for the influence of founder effect in isolation of small initial populations and subsequent rapid morphological differentiation and development of host associations and local adaptation for $H$. placei. Thus, they designated a series of sub- species on the basis of distinct morphological similarity within populations in North America and South America (H. placei argentinensis), Africa (H. placei africanus), and Australia ( $H$. placei placei); all maintained a core association with $B$. taurus and $B$. indicus. Differentiation among these geographically isolated subspecies would have arisen in the past $500 \mathrm{yr}$ after European contact in South America and Australia and would be predicted to be reflected in variation for appropriate genetic loci (Giudici et al., 1999).

The potential for morphological and genetic differentiation and local adaptation within $H$. place $i$ and $H$. similis should also be examined in greater detail between African and IndianAsian populations in view of the history of domestication for cattle. The domestication of cattle is linked to 2 independent events in Africa and India, respectively, both from putative populations or historically discrete subspecies of aurochs, B. primigenius (Loftus et al., 1994). Results of our analyses would suggest African origins for both $H$. placei and $H$. similis and core associations in Bovini, specifically the lineage leading to $B$. taurus, and a later colonization event involving $B$. indicus. Divergent histories for domestic cattle are consistent with introduction and interchange of Haemonchus spp. from African populations of Bos to those in Eurasia and India. Later differentiation of parasite populations would have been influenced by varying temporal and spatial scales. Current data indicate that H. placei is most successful in B. taurus and cattle of European origin, whereas $H$. similis is most abundant among zebu or humped-cattle and water buffalo in tropical and subtropical regions (Gibbons, 1977).

A potential for accelerated adaptation of Haemonchus spp. in domestic stock is suggested. Genetic differentiation of Haemonchus was likely to have been influenced by the relatively deep history of domestication and subsequently shallow temporal events for anthropogenically driven patterns of dispersal for hosts and parasites. For example, domestication of sheep and goats in the Middle East and Eurasia around 12 kybp set the stage for the subsequent global spread of H. contortus (Ryder, 1984). Concurrently, the history of cattle and Haemonchus spp. may be reflected in a similar manner (Giudici et al., 1999). In this regard, Blouin et al. (1995) examined the genetic structure of $H$. contortus and $H$. placei in sheep and cattle in the context of contemporary host transport and husbandry in the United States. They did not examine, however, populations of Haemonchus in such hosts as bighorn sheep, pronghorn, bison, or deer in sympatry with domestic stock or in ecotone conditions at the border of managed and natural ecosystems. If our current hypotheses about the nature of relationships among core and satellite hosts and associations with Haemonchus are corroborated, we would predict that substantial genetic partitions among populations in domestic ruminants and wild cervids and caprine bovids would not be demonstrated. Alternatively, there may also be a role for local adaptation as a determinant of genetic diversity at relatively fine scales within this and other systems.

Durette-Desset et al. (1999) outlined a brief scenario for historical biogeography and host relationships among Haemonchine nematodes. Pertinent is the assertion that species of "Haemonchus, Ashworthius and Mecistocirrus mainly parasitize domestic cattle, but also have species in Cervidae, and wild Bovidae in the Palearctic and Ethiopian zones." On the contrary, 
species of Haemonchus are primarily parasites among wild Antilopinae and Bovinae in sub-Saharan Africa, and only 2 species, $H$. placei and $H$. similis, can be regarded as typical in domestic Bovini, whereas $H$. contortus occurs primarily in Carpini (Tables III, IV). Species of Ashworthius are not known in domestic Bovinae and particularly species of Bos. Ashworthius are typical of wild Bovinae such as Syncerus and Tragelaphus in Africa, Antilopinae such as Antilope cervicapra from India, or were historically distributed among Asian cervids (A. sidemi Schulz, 1933; A. tuyenguangi Dróżdż, 1970) before translocation of the former to the western Palearctic (Ferté and DuretteDesset, 1989; Hoberg et al., 2002). In addition, A. patriciapilittae has an apparently endemic distribution in the cervid $O$. virginianus from Central America (Hoberg et al., 2002). Only $M$. digitatus has a primary distribution among domestic bovids, including Bos spp. and Bubalis bubalis, and has been widely translocated in tropical regions coincidental with introduction of its hosts for agriculture (Lichtenfels and Pilitt, 2000).

The first phylogenetic hypothesis for species of Haemonchus has provided the foundation for the development of a comprehensive understanding of the history of these economically important nematodes. It is clear that much remains to be elucidated, but we have articulated an explicit hypothesis with clearly defined assumptions that appears to have substantial explanatory power on the basis of currently available empirical data for parasite distribution and ecological linkages. We have advanced an argument for the integration of contemporary ecology and phylogeny to reveal insights into the history of species of Haemonchus and the evolution of complex host associations characteristic of these nematodes among artiodactyls. Although points of these analyses may be considered contentious, we suggest that fundamental appreciation of the structure and history of the biosphere may be gained from such an integrative approach. Some general conclusions for Haemonchus are outlined as follows: (1) origins in Africa with basal diversification in antelopes, (2) colonization and development of core host associations within Antilopinae, Bovinae, Caprinae, Giraffidae, and Camelidae, (3) independent events of colonization for those species in domesticated Camelidae, Bovini, and Caprini $(H$. placei, H. contortus, H. similis, H. longistipes), and (4) geographically widespread species are represented only by those that have been translocated with domestic stock. Lastly, the North American fauna is characterized by 3 introduced and exotic species, $H$. placei, $H$. contortus, $H$. similis, which emphasizes the importance of continued documentation of faunal diversity in the context of predictive foundations derived from phylogenetic studies.

\section{ACKNOWLEDGMENTS}

The authors thank Patricia Pilitt and Arthur Abrams of the USNPC for assistance with specimens and comparative literature for Haemonchus and related nematodes.

\section{LITERATURE CITED}

AlmeidA, J. L. DE. 1933. Note sur les espéces du genre Haemonchus Cobb, 1898 (Nematoda-Trichostrongyloidea). Comptes Rendus des Sèances de la Société de Biologie et de ses Filiales 114: 960-961. . 1935. Revisão do genera Haemonchus Cobb, 1898 (Nematoda:

Trichostrongylidae). Memórias do Insituto Oswaldo Cruz 30: 57 114.

Amarante, A. F. T., J. Bagnola JR., M. R. V. Amarante, and M. A.
BARbosa. 1997. Host specificity of sheep and cattle nematodes in Sao Paulo State, Brazil. Veterinary Parasitology 73: 89-104.

Blouin, M. S., C. A. Yowell, C. Courtney, and J. B. Dame. 1995. Host movement and the genetic structure of populations of parasitic nematodes. Genetics 141: 1007-1014.

- - - AND - 1997. Haemonchus placei and Haemonchus contortus are distinct species based on mtDNA evidence. International Journal for Parasitology 27: 1383-1387.

BoOMKeR, J. D. F. 1990. A comparative study of the helminth fauna of browsing antelope of South Africa. Ph.D. Dissertation. Medical University of South Africa, Pretoria, South Africa, 297 p.

Bremer, K. 1994. Branch support and tree stability. Cladistics 10: 295304.

BRoOKS, D. R. 1979. Testing the context and extent of host-parasite coevolution. Systematic Zoology 28: 299-307.

. 1981. Hennig's parasitological method: A proposed solution. Systematic Zoology 30: 229-249.

, A. P. G. Dowling, M. G. P. van Veller, and E. P. Hoberg. 2004. Ending a decade of deception: A valiant failure, a not-sovaliant failure, and a success story. Cladistics 20: 32-41.

- AND E. P. Hoberg. 2000. Triage for the biosphere: The need and rationale for taxonomic inventories and phylogenetic studies of parasites. Comparative Parasitology 67: 1-25.

, AND D. A. MCLENNAN. 1991. Phylogeny, ecology and behavior. A research program in comparative biology. University of Chicago Press, Chicago, Illinois, 434 p.

, AND - 1993. Parascript: Parasites and the language of evolution. Smithsonian Institution Press, Washington D.C., 430 p.

, AND - 2002. The nature of diversity: An evolutionary voyage of discovery. University of Chicago Press, Chicago, Illinois, $668 \mathrm{p}$.

, AND - 2003. Extending phylogenetic studies of coevolution: Secondary Brooks parsimony analysis, parasites, and the Great Apes. Cladistics 19: 104-119.

Bush, A. O., K. D. Lafferty, J. M. Lotz, and A. W. ShostaK. 1997 Parasitology meets ecology on its own terms: Margolis et al. revisited. Jounal of Parasitology 83: 575-583.

Chabaud, A. G. 1965. Spécificité parasitaire. I. Chez sur les Nématodes parasites de Vertébrés In Traité de Zoologie, vol. 4, P. P. Grassé (ed.). Masson, Paris, France, p. 548-557.

. 1971. Evolution of host-parasite adaptation in nematodes of vertebrates. International Journal for Parasitology 1: 217-221.

, F. Puylaert, O. Bain, A. J. Petter, and M. C. Durette-DesSET. 1970. Remarques sur 1'homologie entre les papillaes cloacales des rhabdities et les côtes dorsales des Strongylida. Comptes Rendus Hebdomadaires des Séances de 1'Académie des Sciences (Paris) 271: 1771-1774.

Chilton, N. B., L. A. Newton, I. Beveridge, and R. B. Gasser. 2001 Evolutionary relationships of trichostrongyloid nematodes (Strongylida) inferred from ribosomal DNA sequence data. Molecular Phylogenetics and Evolution 19: 367-386.

DíAz, L., H. Ríoseco, AND V. Cubillos. 1977. Prospección y patologia del parasitismo en cérvidos autóctonos y exóticos en el sur de Chile. Boletin Chileno Parasitologia 32: 86-89.

Dowling, A. P. G. 2002. Testing the accuracy of TreeMap and Brooks parsimony analysis of coevolutionary patterns using artificial associations. Cladistics 18: 416-435.

- M. P. G. van Veller, E. P. Hoberg, And D. R. Brooks. 2003 A priori and a posteriori methods in comparative evolutionary studies of host-parasite associations. Cladistics 19: 240-253.

Durette-Desset, M. C. 1964. Les systèmes d'arêtes cuticulaires chez les Nématodes Heligmosomes: Etude de cinq espèces parasites de Rongeurs de la Maboke. Cahiers de la Maboke 2: 39-78.

. 1983. Keys to the genera of the superfamily Trichostrongyloidea. In $\mathrm{CIH}$ keys to the nematode parasites of vertebrates, R. C. Anderson and A. G. Chabaud (eds.). Commonwealth Agricultural Bureaux, Farnham Royal, U.K., p. 1-86.

. 1985. Trichostrongyloid nematodes and their vertebrate hosts: Reconstruction of the phylogeny of a parasitic group. Advances in Parasitology 24: 239-306.

, I. Beveridge, And D. M. Spratt. 1994. The origins and evolutionary expansion of the Strongylida (Nematoda). International Journal for Parasitology 24: 1139-1165. 

todes Trichostrongyloidea. Annales de Parasitologie Humaine et Comparée 52: 539-558.

— AND - 1981. Nouvel essai de classification des Nématodes Trichostrongyloidea. Annales de Parasitologie Humaine et Comparée 56: 297-312.

$\longrightarrow$, J. P. Hugot, P. Darlu, And A. G. Chabaud. 1999. A cladistic analysis of the Trichostrongyloidea (Nematoda). International Journal for Parasitology 29: 1065-1086.

- AND C. A. SutTon. 1979. Position systématique du genre Boehmiella Gebauer, 1932 (Nematoda: Haemonchinae). Bulletin du Muséum National d'Histoire Naturelle Section A 4ème série 1: 241244.

Ferté, H., And M.-C. Durette-Desset. 1989. Redescription d'Ashworthius sidemi Schulz, 1933 et d' A. gagarini Kostyaev, 1969 (Nematoda: Trichostrongyloidea), parasites de Cervidae. Bulletin du Muséum National d'Histoire Naturelle 11: 69-77.

Gatesy, J., A. Amato, E. Vrba, G. Schaller, and R. DeSalle. 1997. A cladistic analysis of mitochondrial ribosomal DNA from the Bovidae. Molecular Phylogenetics and Evolution 7: 303-319.

- AND P. ARCTANDER. 2000. Molecular evidence for the phylogenetic affinities of ruminants. In Antelopes, deer, and relatives: Fossil record, behavioral ecology, systematics and conservation, E. S. Vrba and G. B. Schaller (eds.). Yale University Press, New Haven, Connecticut, p. 143-155.

Gebauer, O. 1932. Böhmiella perichitinea n. sp. ein neuer Trichostrongylidae (Nematoda) ein Nutria. Zeitschrift für Parasitenkunde 4: 730-736.

Gentry, A. W. 2000. The ruminant radiation. In Antelopes, deer, and relatives: Fossil record, behavioral ecology, systematics and conservation, E. S. Vrba and G. B. Schaller (eds.). Yale University Press, New Haven, Connecticut, p. 11-25.

GibBons, L. M. 1977. Morphology of the superfamily Trichostrongyloidea (Nematoda) with special reference to those occurring in African Artiodactyla. Ph.D. Dissertation. University of London, London, U.K., 333 p.

1979. Revision of the genus Haemonchus Cobb, 1898 (Nematoda: Trichostrongylidae). Systematic Parasitology 1: 3-24.

—, AND L. F. KHALIL. 1982. A key for the identification of genera of the nematode family Trichostrongylidae Leiper, 1912. Journal of Helminthology 56: 185-233.

GibBs, H. C., AND R. P. HeRD. 1986. Nematodiasis in cattle: Importance species involved, immunity and resistance. In The veterinary clinics of North America. Parasites: Epidemiology and control, vol. 2., no. 2, H. C. Gibbs, R. P. Herd, and K. D. Murrell (eds.). W.B. Saunders, Philadelphia, Pennsylvania, p. 211-224.

Giudici, C. J., J. Cabaret, and M. C. Durette-Desset. 1999. Description of Haemonchus placei (Place, 1893) (Nemaoda, Trichostrongylidae, Haemonchinae), identification and intra-specific morphological variability. Parasite 6: 333-342.

GouŸ De BellocQ, J. G., H. Ferté, J. Depaquit, J.-L. Justine, A. TILLeR, AND M. C. Durette-Desset. 2001. Phylogeny of the Trichostrongylinae (Nematoda) inferred from $28 \mathrm{~S}$ rDNA sequences. Molecular Phylogenetics and Evolution 19: 430-442.

Hassanin, A., And E. J. P. DouZery. 2003. Molecular and morphological phylogenies for the Ruminantia and the alternative position of the Moschidae. Systematic Biology 52: 206-228.

HoberG, E. P. 1997a. Phylogeny and historical reconstruction: Hostparasite systems as keystones in biogeography and ecology. In Biodiversity II: Understanding and protecting our resources, M. ReakaKudla, D. E. Wilson, and E. O. Wilson (eds.). Joseph Henry Press, Washington, D.C., p. 243-261.

- 1997b. Parasite biodiversity and emerging pathogens: A role for systemaics in limiting impacts on genetic resources. In Global genetic resources: Access, ownership and intellectual property rights, K. E. Hoaglund and A. Y. Rossman (eds.). Association of Systematics Collections, Washington, D.C., p. 71-83.

- A. Abrams, R. Carreno, and J. R. Lichtenfels. 2002. Ashworthius patriciapilittae $\mathrm{n}$. sp. (Trichostrongyloidea: Haemonchinae), an abomasal nematode in Odocoileus virginianus from Costa Rica, and a new record for species of the genus in the Western Hemisphere. Journal of Parasitology 88: 1187-1199.

—, A. A. KoCAN, AND L. G. RICKARD. 2001. Gastrointestinal stron- gyles in wild ruminants. In Parasitic diseases of wild mammals, W. M. Samuel, M. J. Pybus, and A. A. Kocan (eds.). Iowa State University Press, Ames, Iowa, p. 193-227.

- S. J. Kutz, K. E. Galbreath, and J. Cook. 2003. Arctic biodiversity: From discovery to faunal baselines-revealing the history of a dynamic ecosystem. Journal of Parasitology Supplement 89: S84-S95.

, AND J. R. LICHTENFELS. 1994. Phylogenetic systematic analysis of the Trichostrongylidae (Nematoda) with an initial assessment of coevolution and biogeography. Journal of Parasitology 80: 976996.

, K. Monsen, S. Kutz, And M. S. Blouin. 1999. Structure, biodiversity, and biogeography of nematode faunas in Holarctic ruminants: Morphological and molecular diagnoses for Teladorsagia boreoarcticus sp. n. (Nematoda: Ostertagiinae) a dimorphic cryptic species in muskoxen (Ovibos moschatus). Journal of Parasitology 85: 910-934.

HorAK, I. G. 1980. The incidence of helminths in sheep, pigs, cattle, impala and blesbok in the Transvaal. Ph.D. Dissertation. University of Natal, Pietermaritzburg, South Africa, $201 \mathrm{p}$.

Jacquiet, P., J. F. Humbert, A. M. Comes, J. Cabaret, A. Thiam, And D. CHEIKH. 1995. Ecological, morphological and genetic characterization of sympatric Haemonchus spp. parasites of domestic ruminants in Mauritania. Parasitology 110: 483-492.

- J. CABARET, D. CheIKH, AND E. ThiAm. 1997. Identification of Haemonchus species in domestic ruminants based on morphometrics of spicules. Parasitology Research 83: 82-86.

Kurtén, B., AND E. Anderson. 1980. Pleistocene mammals of North America. Columbia University Press, New York, 442 p.

LE JAMBre, L. F. 1983. Pre-mating barriers to species hybridization in Haemonchus. International Journal for Parasitology 13: 365-370.

LiCHTENFELS, J. R. 1977. Differences in cuticular ridges among Cooperia spp. of North American ruminants with an illustrated key to species. Proceedings of the Helminthological Society of Washington 44: 111-119.

. 1987. Phylogenetic inference from adult morphology in the Nematoda; with emphasis on the bursate nematodes, the Strongylida; advancements (1982-1985) and recommendations for further work. International Journal for Parasitology 17: 269-279.

, AND E. P. Hoberg. 1993. The systematics of nematodes that cause ostertagiasis in domestic and wild ruminants in North America: An update and key to species. Veterinary Parasitology 46: 3353.

, AND P. A. PILITT. 1983. Cuticular ridge patterns of Nematodirus (Nematoda: Trichostrongyloidea) parasitic in domestic ruminants of North America with a key to species. Proceedings of the Helminthological Society of Washington 50: 261-274.

- AND 2 2000. Synlophe patterns of the Haemonchinae of ruminants (Nematoda: Trichostrongyloidea). Journal of Parasitology 86: 1093-1098.

$\longrightarrow, \longrightarrow$, L. M. GibBons, And J. D. F. Boomker. 2001. Hae monchus horaki n. sp. (Nematoda: Trichostrongyloidea) from the grey rhebuck Pelea capreolus in South Africa. Journal of Parasitology 87: 1095-1103.

$\longrightarrow,-,-$ AND E. P. HoBERG. 2002. Redescriptions of Haemonchus mitchelli and Haemonchus okapiae (Nematoda: Trichosytrongyloidea) and description of a unique synlophe for the Haemonchinae. Journal of Parasitology 88: 947-960.

,-- AND E. P. HoBERG. 1994. New morphological characters for identifying individual specimens of Haemonchus spp. (Nematoda: Trichostrongyloidea) and a key to species in ruminants of North America. Journal of Parasitology 80: 107-119.

-, AND L. F. LE JAMBRE. 1986. Cuticular ridge patterns of Haemonchus contortus and Haemonchus placei (Nematoda: Trichostrongyloidea). Proceedings of the Helminthological Society of Washington 53: 94-101.

- - AND —. 1988. Spicule lengths of the ruminan stomach nematodes Haemonchus contortus, Haemonchus placei, and their hybrids. Proceedings of the Helminthological Society of Washington 55: 97-100.

, AND W. P. WERGIN. 1994. Sublateral hypodermal cords in Haemonchus (Nematoda: Trichostrongyloidea): Description and potential as a systematic character. Journal of Parasitology 80: 620-624. 
Loftus, R. T., D. E. MacHugh, D. G. Bradley, And P. M. Sharp. 1994. Evidence for two independent domestications of cattle. Proceedings of the National Academy of Sciences of the United States of America 91: 2757-2761.

Maddison, W. P. M., M. J. Donoghue, And D. R. Maddison. 1984. Outgroup analysis and parsimony. Systematic Zoology 33: 83-103.

Maddison, D. R., AND W. P. MAdDison. 2000. MacClade 4.0, program and manual. Sinauer Associates, Sunderland, Massachusetts, 492 p.

PAGE, R. D. M. (ED.). 2002. Tangled trees. University of Chicago Press, Chicago, Illinois. 350 p.

RYDER, M. L. 1984. Sheep. In Evolution of domesticated animals, I. L. Mason (ed.). Longman Incorporated, New York, p. 63-85.

Siddall, M. E., AND S. L. PERKINS. 2003. Brooks parsimony analysis: A valiant failure. Cladistics 19: $554-564$.

Skrjabin, K. I., N. P. Shikhabalova, And R. S. Shul'ts. 1954. Trichostrongylids of animals and man. Osnovy Nematodologii III. Academy of Sciences, USSR, Moscow, USSR. [English Translation, 1960. Israel Program for Scientific Translations, Jerusalem, 704 p.]

Stevenson, L. A., N. B. Chilton, And R. Gasser. 1995. Differentiation of Haemonchus placei from $H$. contortus (Nematoda: Trichostrongylidae) by ribosomal DNA second internal transcribed spacer. International Journal for Parasitology 25: 483-488.
SWOFFORD, D. 2001. PAUP $4.0 b 10$ computer program for MacIntosh. Sinauer Associates, Sunderland, Massachusetts.

Vicente, J. J., H. O. Rodrigues, D. C. Gomes, and R. M. Pinto. 1997. Nematoides do Brasil. Parte V: Nematoides de mamiferos. Revista Brasileira de Zoologica 14(Suppl. 1): 1-452.

VRBA, E. S. 1985. African Bovidae: Evolutionary events since the Miocene. South African Journal of Science 81: 263-266.

1995. The fossil record of African antelopes (Mammalia: Bovidae) in relation to human evolution and paleoclimate. In Paleoclimate and evolution with emphasis on human origins, E. S. Vrba, G. S. Denton, T. C. Partridge, and L. H. Burckle (eds.). Yale University Press, New Haven, Connecticut, p. 385-424.

, AND G. B. Schaller. 2000. Phylogeny of Bovidae based on behavior, glands, skulls, and postcrania. In Antelopes, deer, and relatives: Fossil record, behavioral ecology, systematics and conservation, E. S. Vrba and G. B. Schaller (eds.). Yale University Press, New Haven, Connecticut, p. 203-222.

Watrous, L. E., AND Q. D. WHEELER. 1981. The outgroup comparison method of character analysis. Systematic Zoology 30: 1-11.

Zarlenga, D. S., F. Stringfellow, M. NobARy, AND J. R. LiChtenfels. 1994. Cloning and characterization of ribosomal RNA genes from three species of Haemonchus (Nematoda: Trichostrongyloidea) and identification of PCR primers for rapid differentiation. Experimental Parasitology 78: 28-36. 